RUNNING TITLE: South Georgia foodweb model

2

3

4

5

6

7

8

9

\title{
A foodweb model to explore uncertainties in the South Georgia
} shelf pelagic ecosystem.

Research II, 59-60. 237-252. 10.1016/j.dsr2.2011.09.001 
inconsistency was that estimated consumption of fish was 5 times their estimated production. We developed a static mass balance model of the foodweb representing one of many possible solutions to the inconsistencies in the data. The model included sufficient fish biomass to balance the original consumption estimate, and consequently fish became the main krill consumers. Nonetheless, only $74 \%$ of local krill production was consumed by predators, suggesting that there are important mortality sources which we did not explicitly model. We developed further models to explore scenarios incorporating plausible climatedriven reductions in krill biomass. In scenarios with unchanged predator diets, an $80 \%$ reduction in krill biomass resulted in a $73 \%$ reduction in vertebrate biomass. However, when predators with diverse diets were able to switch to feeding on alternative zooplankton prey, total vertebrate biomass was maintained at current levels. Scenarios in which $80 \%$ of krill biomass was replaced with copepod biomass required $28 \%$ more primary production because the estimated consumption rate of copepods is higher than that of krill. The additional copepod biomass did not alter the consequences for vertebrates. These scenarios illustrate the wide range of potential consequences of a shift from a krill to a copepod dominated system in a warming climate. They suggest that both maintenance and dramatic reduction of vertebrate production are plausible outcomes, although the former requires major changes in predator diets.

KEY WORDS: Foodweb model, climatic changes, competitors, primary production, ecosystem services. 


\section{INTRODUCTION}

Antarctic krill, Euphausia superba, plays a major role in the pelagic marine foodweb on the South Georgia shelf (Atkinson et al., 2001; Murphy et al., 2007a). It is an important prey item for many vertebrate predators including demersal and pelagic fish, mammals, and seabirds (Croxall et al., 1997; Main et al., 2009; Reid \& Arnould, 1996; Shreeve et al. 2009). Krill are also one of the main metazoan grazers of phytoplankton and therefore a major regulator of production and nutrient flows (Atkinson and Whitehouse 2001; Schmidt et al., 2011a; Whitehouse et al., 2008, 2011a). In addition to these direct trophic interactions, krill might have indirect competitive interactions with other grazers. Observations at South Georgia suggest that high copepod abundance coincides with relatively low krill abundance (Atkinson et al., 1999). When krill are scarce, some ordinarily krill-feeding predators switch to carnivorous macroplankton which, in turn, feed mainly on copepods (Croxall et al., 1999). The abundance of krill in the South Georgia shelf system is highly variable. This variability can include years of famine, such as the summer of 2008/09 when krill was virtually absent from the diets of many predators and there were no fishery catches (BAS unpublished data). Such events are almost certainly linked to climate variability. South Georgia is near the northern limit of krill's distribution, and the variability in its local and regional abundance is correlated with climatic indices (Murphy et al. 2007b; Whitehouse et al., 2008). These relationships, combined with decreases in krill recruitment and abundance within the Scotia Sea (Atkinson et al., 2004; Siegel and Loeb, 1995; Trivelpiece et al. 2011) have led to predictions that plausible climate change could remove most of the krill from the South Georgia shelf, causing a prolonged extension of the conditions observed in 2008/09 (Mackey et al., this issue; Murphy et al., 2007b). 
the structure of the wider foodweb. Such changes could also affect critical aspects of foodweb operation including its resilience to further change, and therefore its ability to support ecosystem services including production of commercially harvested species, carbon cycling, and the biodiversity which underpins wildlife tourism. It is therefore important to understand the potential consequences of climate induced change for the structure and operation of the ecosystem.

The marine ecosystem around South Georgia is one of the most studied in the

Southern Ocean. It was frequently surveyed during the Discovery Expeditions between 1928 and 1935 because of its importance to the whaling industry, and it is currently the focal area for many of the British Antarctic Survey's marine ecological studies. It would be valuable to bring the abundant available data together to produce a quantitative description of the ecosystem. A useful first step in this direction is to describe the foodweb. The widely used Ecopath foodweb modelling framework (Christensen and Pauly, 1992) provides a useful template for compiling relevant data on biomass, rate processes, and feeding relationships. This is particularly useful for identifying gaps and inconsistencies in the data. Ecopath can also be used to model the propagation of change (induced, for example, by harvesting and climate) through the foodweb to identify plausible consequences. This study develops a quantitative description of the South Georgia shelf pelagic foodweb with the particular aim of identifying major inconsistencies in the data and evaluating the trophic roles of krill and copepods. It also uses foodweb models to explore how changes in krill abundance might affect both zooplankton and vertebrate predators, and how these impacts might be modulated by flexibility in predator diets. 


\section{METHODS}

\subsection{Database}

We developed a foodweb model to investigate how changes to the zooplankton

might impact the abundant vertebrate predators concentrated around South Georgia. These predators and their prey interact with other larger ecosystems (including the Scotia Sea to the South and the Antarctic Circumpolar Current system) at a variety of scales (Murphy et al., 2007a). The South Georgia shelf pelagic system is a pragmatic scale to develop a foodweb model to address these questions, partly because many of the available data are more applicable to this system than to the larger scale and partly because this system encloses both the breeding colonies of seabirds and seals on the South Georgia archipelago and the entire habitat of the shelf's demersal fish. The choice of scale and focus is reflected in the model structure including: the choice of functional groups, which are resolved to species level for many vertebrates but are more aggregated for invertebrates and basal

We compiled available information on the pelagic foodweb of the South Georgia shelf to construct an Ecopath dataset. For the purposes of this study, the boundaries of this ecosystem are the shoreline of South Georgia and the 1,000m bathymetric contour, encompassing an area of 45,530 $\mathrm{km}^{2}$ (Fig. 1). The dataset nominally represents the average state of the foodweb during the past decade. 

foodweb models (Christensen and Walters, 2004). It describes foodwebs in terms of the biomass, consumption, production rates and diets of species or life stages aggregated into functional groups on the basis of trophic similarity. These parameters are described in a consistent metric, which was wet mass $\mathrm{km}^{-2}$ in this case. Ecopath is used to produce massbalance models which obey the logical constraint that the consumption of any trophic group cannot exceed production by that group over some appropriate time period, which was one year in this case. Production can, however, exceed consumption and this difference is described in the "ecotrophic efficiency" (EE) parameter which we discuss later. Following a review of the available information and consultation with the experts listed in the Supplementary Information (SI), we structured the model around 30 functional groups (Table 3). The vertebrates were grouped on the basis of taxonomy and similarity of adult diets, and invertebrates were aggregated on the combined basis of data availability and functional similarity. The names of these functional groups are given in italics throughout the text. Compiling this information was a detailed process drawing on a range of sources (primary and grey literature, unpublished datasets, expert opinion, and proxies from other species and areas) and sometimes requiring subjective interpretation. Our summary of the available data is defensible but there is considerable uncertainty in this (and any pelagic foodweb dataset) which has not been possible to fully characterise. This could mean that there are alternative, equally defensible values for many of our input data. It is good practice to ensure that each value in the input data is traceable to its source and any manipulations are transparent and repeatable. This allows readers to assess the validity of 
any value. Due to space constraints, this information is provided in the SI using a tabular format. A summary of this information for the zooplankton functional groups is given in Table 1.

The detritus (DET) group in many Ecopath models represents all non-living organic material from dissolved organic matter to the carcasses of large animals. Any modelled production that is not assimilated by predators or otherwise explicitly accounted for (e.g. biomass accumulation, fishery removals, other exports) becomes detritus. The consumption or assimilation of non-living organic material by any functional group is modelled by including detritus in that group's diet (but see Pinkerton et al., 2008). This is largely true of the current study with two important caveats. Firstly, we used the model balancing process phytoplankton (phytodetritus) are important diet components for various organisms including krill (Schmidt et al., 2011a) and benthic deposit feeders. We used the approach of Pinkerton et al. $(2008,2010)$ and modelled this trophic interaction as direct feeding on primary producers (PHY). We also represented the diet of heterotrophic bacteria as $100 \%$ production required without impacting the other results and conclusions of the study. Secondly, when changes were made because the EE of a prey group was $>1$, the change made was to reduce its EE to approximately 1 (see section 2.2). Thus, almost all production of the prey group was consumed by predators in the resulting balanced model. This could potentially understate the contribution of these prey groups to the detritus pool and 
uncommon, and local reproduction appears insufficient to maintain the krill stock (Tarling et al., 2007). The majority of the available krill are probably imported into the system on ocean currents (Murphy et al., 2004). Many of the air-breathing vertebrates that feed in this system spend much of their time on land, where they produce offspring, defecate and may die. Many of these animals are also highly migratory with ambits that may extend to thousands of kilometres, but which congregate at South Georgia to feed, breed or both. We scaled biomass by the fraction of the year that groups are resident, so that prey consumption within the system was also scaled appropriately. We distinguished between off-shelf krill (EIM1) and other off-shelf prey (EIM2) in predator diets. Off-shelf feeding results in an import of material into the modelled system. However, we defined EIM1 and EIM2 as explicit groups within the model, each of which fed entirely on "Import" (an Ecopath function to represent feeding outside the modelled system). We gave off-shelf krill the production to biomass ratio (P/B) and consumption to biomass ratio $(\mathrm{Q} / \mathrm{B})$ of krill, and other off-shelf prey the $\mathrm{P} / \mathrm{B}$ and $\mathrm{Q} / \mathrm{B}$ of pelagic fish, and we set their biomasses to satisfy predator demand for off-shelf prey in the base model. This structure allowed us to reduce the availability of off-shelf krill to explore scenarios incorporating a reduction in the krill

177 biomass available to predators both on and off the South Georgia shelf. These import groups were excluded from the calculation of statistics (e.g. total production) for the modelled system. Baleen whales barely feed when they migrate out of the Southern Ocean to breed, but they can migrate extensively while foraging in the Southern Ocean. We represented baleen whales using mean abundances $\mathrm{km}^{-2}$ and feeding rates for the Scotia 
Sea (Reilly et al. 2004) so there was no need to explicitly represent import consumption, or rescale biomass for this group.

We did not explicitly model advective import of krill into the South Georgia shelf ecosystem but we estimated krill production rates based on growth alone (i.e. without a contribution from recruitment). The assumption of zero net imports is pragmatic in the absence of information about the relative magnitude of imports and exports and is useful for assessing whether krill local production is sufficient to meet local demand (e.g. Gilpin et al. 2002; Trathan et al. 1995) but there are plausible alternative scenarios (see Discussion). The South Georgia shelf ecosystem is characterised by high inter-annual variability and some particularly extreme events have occurred in the last decade. The mass balance constraint is unlikely to apply over any one year in a highly variable system. The balanced models do not therefore represent any specific year but the average state during a longer period over which the assumption of mass balance is likely to be valid. Ecosystems may also exhibit long term trends in addition to interannual fluctuations. Ecopath models can include a biomass accumulation term to account for such changes over time. However, the available data are not sufficient to describe the dynamics of the whole foodweb so we used the traditional modelling approach of a steady-state approximation for simplicity.

The South Georgia shelf is a fished ecosystem. Average catches in the wider South Georgia area (FAO statistical area 48.3) were 43,565 t.yr ${ }^{-1}$ in the period 2001 to 2009 (CCAMLR 2011). These included 37,305 t.yr ${ }^{-1}$ of krill and 1,941 t.yr ${ }^{-1}$ of mackerel icefish, which were respectively caught mainly and entirely in the modelled area. We did not model these removals which are equivalent to $1 \%$ and $7 \%$ of the krill and mackerel icefish 
production in the input (base) data, and $1 \%$ of the mackerel icefish production in the balanced (base) model.

206

207 equations for each functional group, $i$ :

and $\quad Q_{i}=P_{i}+R_{i}+G S_{i} \cdot Q_{i}$

where $B_{i}$ is biomass and $P_{i} / B_{i}$ is the production to biomass ratio of group $i$. The sum term is the total predation on group $i$, where $Q_{j} / B_{j}$ is the consumption to biomass ratio of predator $j$ and $D C_{j i}$ is the proportional contribution of prey $i$ to the diet of predator $j$. Additional terms account for fishery catches $\left(Y_{i}\right)$, net import $\left(E_{i}\right)$ and biomass change ( $\left.B A_{i}\right) . Q_{i}, P_{i}$ and $R_{i}$ are, respectively, the consumption, production and respiration of group $i$ over the model time step. $G S_{i}$ is the fraction of consumption that is not assimilated by the predator because it is lost through messy eating, defecation, urination etc ( $G S_{i}$ was set to the Ecopath default value of 0.8 for each group in this study). $E E_{i}$, the ecotrophic efficiency, is the consumption of group $i$ by predators divided by the production by group $i$ $\left(B_{i} \cdot P_{i} / B_{i}\right)$. Therefore a dataset that satisfies the constraint that consumption of any

222 functional group over some time period cannot exceed production by that group over the same period will allow a solution to the system of linear equations, with $E E_{i}$ in $[0,1]$, for each functional group. 
some of the values in the input (base) dataset to produce a balanced (base) model. We used manual balancing, which is the most common approach. We adjusted input values one at a time without the aid of an automated procedure. There have been various attempts to make this an entirely objective process, sometimes with the uncertainty in a particular value governing the magnitude of permitted changes (Kavanagh et al., 2004; Pinkerton et al. 2008, 2010). However, all approaches carry the risk that any revised value will be a less accurate reflection of reality than the original input value. We made changes within a clearly defined set of rules and provide a record of each step in the balancing process to allow readers to assess the validity of these changes and their consequences (see SI). The key rules were:

(1) The base model (representing the "current" foodweb) was balanced primarily which are unlikely to have $\mathrm{EE}=1$ because they are unlikely to be consumed by predators and juvenile toothfish, for which the shelf is a nursery area and which therefore export biomass from the shelf. Because we did not explicitly model this export, the models recycle juvenile 
base model. Subsequent alterations to predators of affected prey groups could result in EEs $<1$.

We produced an initial balanced (base) model to represent the average state of the

South Georgia shelf pelagic foodweb in the last decade. This became the starting point for

exploring four scenarios which are summarised in Table 2 and which we modelled by adapting the initial balanced (base) model, rather than the input dataset. The base model and the four scenarios are "snapshots" of possible foodwebs which obey the mass balance constraint. All four scenarios include an $80 \%$ reduction in krill biomass, which is the difference between the average and minimum estimates of krill density near South Georgia from annual acoustic surveys conducted during the summer predator feeding season (Hill et al., 2005) and is a plausible long-term consequence of future climate change (Murphy et al., 2007b). As explained above, we modelled a large scale reduction in krill biomass so it affected the availability of krill both on and off-shelf. The scenarios also explore the possibility that copepod biomass could increase as krill biomass is reduced, which might be expected if krill is indeed competitively dominant to copepods (Atkinson et al. 1999). Also they explore the possibility that krill predators could switch to feeding on other zooplankton groups, which were the only alternative prey for which substantial unused production was available (indicated by $E E<1$ ) in our balanced (base) model. Together, the four scenarios consider all combinations of copepod expansion versus no expansion and predator switching versus no switching.

Diet switching was implemented using an iterative process to identify the appropriate proportions of the krill and off-shelf krill components of predator diets to switch to copepods or carnivorous macroplankton: 
macroplankton, the krill component of the diet was reduced to (1-X) and the off-shelf krill component was reduced to (1-X1) of its initial amount where $X$ and $X 1$ are in $[0,1]$.

the diet was increased by $\mathrm{X}^{*}$ the krill component plus X1*the off-shelf krill component of the diet.

- If a predator's diet included krill and carnivorous macroplankton but not copepods, the carnivorous macroplankton component of the diet was increased by $\mathrm{X}^{*}$ the krill component plus X1*the off-shelf krill component of the diet.

- $\quad$ These steps were applied simultaneously across all predators to

identify values of $X$ and $X 1$ resulting in $E E$ for krill of 1 . We used a similar procedure

to determine the proportion of the carnivorous macroplankton component of predator diets to switch to copepods. each step in the balancing process.

\section{RESULTS}

\subsection{Base data and model balancing}

Table 1 gives details of the derivation of the base dataset values for the zooplankton and krill groups while the SI provides details for all functional groups (summarised in Table summarised below. 

modelled system, but only $3,058 \mathrm{t} \cdot \mathrm{km}^{-2} \cdot \mathrm{yr}^{-1}$ of production of which about half was primary production (Table 5). The demersal fish groups in particular were out of balance.

Consumption of these groups was $508 \%$ of their estimated production. To balance the base model we increased demersal fish biomass to $697 \%$ of the value suggested by the base dataset and we reduced the importance of demersal fish in the diets of other demersal fish (Table 4). We increased the biomass of pelagic fish (to $289 \%$ of the base value), heterotrophic bacteria (428\%) and primary producers (176\%) to match the consumption estimates. We increased the P/B ratio of cephalopods (123\%) and heterotrophic bacteria (333\%) to satisfy demand. These were the only alterations we made to $\mathrm{P} / \mathrm{B}$ or $\mathrm{Q} / \mathrm{B}$ values.

The former was mainly to break a cycle that existed because cephalopds and demersal fish (specifically juvenile toothfish) prey on each other, meaning that it is impossible to balance macroplankton using the switching rule defined in the Methods. A switch of $81 \%$ of the krill fraction (and $79 \%$ of the off-shelf krill fraction) of the diet to alternative prey resulted in full utilisation of krill production (i.e. EE for krill=1). However, this increased EE for carnivorous 
macroplankton above 1 , and a switch of $92 \%$ of the carnivorous macroplankton fraction of the resulting diets to copepods was necessary to restore EE to 1 . We also increased the biomass of heterotrophic microplankton, heterotrophic bacteria and primary producers to balance models S3 and S4. An 80\% reduction in krill biomass (compared to the base model) reduced the primary production required to support the system by only $4 \%$ (models S1 and S2) whereas a corresponding increase in copepod biomass resulted in a $23 \%$ increase in the primary production required (models S3 and S4), alongside increased requirements for microplankton and bacteria, which are also components of copepod diets. This increased demand resulted from the higher consumption rate of copepods compared to krill. higher overall EEs than their non-switching counterparts (S2>S1 and S4>S3) and the increased copepod models (S3 and S4) had higher overall EEs than their no-increase counterparts (S3>S1 and S4>S2). These differences reflect the balancing process: We calculated the biomass reduction in the switching scenarios to result in full utilisation of krill production, while increased consumption by copepods increased the consumption of the substantial heterotrophic microplankton production.

\subsection{The trophic role of krill}

Krill consumed $9 \%$ of the primary production in the base dataset and $5 \%$ in the base model. Krill were also major consumers of heterotrophic microplankton (15\% of ZHT production in the base dataset and base model). The $314 \mathrm{t} \cdot \mathrm{km}^{-2} \cdot \mathrm{yr}^{-1}$ estimated consumption by krill translated into $79 \mathrm{t} \cdot \mathrm{km}^{-2} \cdot \mathrm{yr}^{-1}$ of krill production. According to the base dataset the EE 
of krill is 0.34 . Increased krill predation in the base model, due mainly to higher fish biomass, increased EE for krill to 0.74 (Table 6). This value was maintained in the non-switching scenarios (S1 and S3) whereas in switching scenarios (S2 and S4) the balancing process resulted in an EE of 1 for krill. consumers, accounting for $25 \%$ of total krill consumption (Fig 2). As a result of biomass increases in the balancing process, demersal fish became the main krill consumers in the base model. Mackerel icefish and minor shelf fish together accounted for $47 \%$ of krill consumption, the remaining demersal fish groups accounted for $6 \%$ and pelagic fish a important (37\%) in switching scenarios.

Baleen whales included both krill and copepods in their diets; gentoo penguins, macaroni penguins, mackerel icefish and other icefish included both krill and carnivorous macroplankton, and diverse flying birds, small rock cod, other shelf fish, pelagic fish and cephalopods included all three. These predators therefore switched diets in scenarios S2 and S4.

Demersal fish were the main krill consumers in the non-switching scenarios (S1 and S3) and the second most important in switching scenarios (S2 and S4), accounting for 68\% and $36 \%$ of krill consumption respectively. This reduction in switching scenarios was because many fish switched diets whereas fur seals and most birds did not. Pelagic fish were also important in non-switching scenarios (13\%) whereas Antarctic fur seals became 


\subsection{Trophic role of copepods}

Copepods were about three times more important consumers of primary production than krill, removing $25 \%$ in the base dataset and $14 \%$ in the base model. They also removed $50 \%$ of heterotrophic microplankton production in both the base data and base model. The $950 \mathrm{t} . \mathrm{km}^{-2} \cdot \mathrm{yr}^{-1}$ estimated consumption by copepods translated into $237 \mathrm{t} \cdot \mathrm{km}^{-2} \cdot \mathrm{yr}^{-1}$ of copepod production. According to the base dataset the EE of copepods is $42 \%$. This rose slightly to $50 \%$ in the base model and was in the range $23 \%$ to $77 \%$ in the scenario models. Carnivorous macroplankton were the most important copepod consumers in the base dataset (89\%: Fig 3) and all balanced models ( $87 \%$ in the base model, $57 \%$ in switching scenarios and $97 \%$ in no-switching scenarios). Biomass increases during the balancing process increased the importance of pelagic fish as copepod consumers in the base model (4\%) compared to the base data (2\%). In the switching scenarios, vertebrates which normally feed mainly on krill became important copepod consumers, with flying birds accounting for $19 \%$ of copepod consumption, and pelagic (19\%) and demersal (2\%) fish increasing consumption compared to the base model

\subsection{Comparing scenarios}

A reduction in krill biomass without predator switching reduced the biomass and production of the many krill-eating groups. Compared to the base model, S1 and S3 had $82 \%$ less mammal biomass, $50 \%$ less penguin biomass, $94 \%$ less flying bird biomass, a $73 \%$ reduction in both pelagic and demersal fish and an $83 \%$ less cephalopods. The high copepod and carnivorous macroplankton production suggested by the base dataset was sufficient to make up the shortfall of krill in predator diets in each of the switching scenarios. 
Consequently, introducing more copepods into the system (S3 and S4) had no effect on

higher trophic levels (compared to the base model) due to the balancing approach (i.e.

higher trophic level biomass was not expanded to take advantage of increased prey availability).

Production by all zooplankton groups including krill (but excluding heterotrophic microplankton) was reduced by $15 \%$ as a result of an $80 \%$ reduction in krill biomass, but the net increase was $38 \%$ when the missing krill biomass was replaced with copepods (scenarios S3 and S4), because the P/B for copepods was 358\% of that for krill.

In the base data, production by pelagic fish was slightly higher than that by demersal

fish but the adjustments made in balancing increased demersal fish production above that of pelagic fish (Fig 4). This ranking was preserved in all scenarios. In the switching scenarios (S2 \& S4), the production of all vertebrates was maintained at the levels of the base model initial balancing had affected the trophic levels of several demersal fish groups, particularly that of other icefish, which was reduced by 0.17 compared to the base data. The switching scenarios resulted in increased trophic levels for most krill-eating groups whereas the trophic level of some groups, notably pelagic fish and king penguins fell, due to the switch from carnivorous macroplankton to copepods.

406

407

3.5 The role of imports 
their diet from outside the modelled system (Table 4). This accounted for $1.2 \%$ of the total consumption in the base dataset $\left(83 \mathrm{t} \cdot \mathrm{km}^{-2} \cdot \mathrm{yr}^{-1} ; 70 \%\right.$ of all consumption by birds and mammals). The relative importance of import consumption was reduced to $1.1 \%$ of total consumption in the base model. Import consumption fell to $6 \mathrm{t} \cdot \mathrm{km}^{-2} \cdot \mathrm{yr}^{-1}$ in models S1 and S3 but accounted for only slightly less $(69 \%)$ of the total consumption by the reduced populations of birds and mammals in these models. In the switching scenarios (S2 and S4), predators could replace off-shelf krill in their diets with on-shelf carnivorous macroplankton and copepods. This reduced import consumption to $55 \mathrm{t} \cdot \mathrm{km}^{-2} \cdot \mathrm{yr}^{-1}$ (47\% of consumption by birds and mammals). Nonetheless, the unused copepod production, (1-EE)*P, exceeded import consumption in all models.

\subsection{Summary}

These results provide a quantitative description of trophic relationships on the South

Georgia shelf and highlight the uncertainties associated with the current dataset, which required ten-fold increases in the biomass estimates for some groups to balance the model. The base model is one of many possible models of the state of the foodweb over the past decade. The scenario models suggest that unchanged copepod production could support the currently observed levels of upper trophic level biomass if predators can switch most of their krill consumption to copepods and carnivorous macroplankton. 

important and intensively studied pelagic ecosystems in the Southern Ocean. This data compilation and the balanced foodweb model quantify the relative importance of a range of feeding relationships and highlight some of the key uncertainties. The whole foodweb context provides a broader perspective than many previous studies (e.g. Croxall et al., 1984; approach before considering what it reveals about the structure and operation of the foodweb. We conclude by discussing what the scenario models suggest about responses to change.

\subsection{Caveats and uncertainties}

The South Georgia pelagic ecosystem is often described as a krill-based system, characterised by iconic krill predators such as fur seals and penguins (e.g. Croxall et al., 1985). The structure of our models and the precision in our estimates reflects the way this view has focused studies of the system. There is a mismatch between the distribution of research effort amongst trophic groups and their importance in total energy flow. Information is particularly scarce for basal groups including primary producers and heterotrophic bacteria. In our models, these uncertainties have minimal effect on the upward propagation of changes to krill and zooplankton. Nonetheless it is appropriate to acknowledge that their potential magnitude might outweigh many of the other uncertainties that we discuss. not indicate bias. Bias can arise from methods that produce over- or underestimates, do not 
encompass the full range of spatial and temporal variability, or rely on assumed parameter values or conversion factors. Other issues arise from model structures. Particular problems with this type of foodweb model are due to simplification. Dynamic processes operate on many different time scales (Murphy et al., 1988) and converting the data to a common time scale (in this case one year) often requires some extrapolation. This is an important issue for the South Georgia ecosystem, which is highly variable both within and between seasons, whereas most of the available data were collected over relatively short periods, usually during the summer when measured biomass, production and consumption might not be representative of annual averages. Furthermore, aggregation into functional groups causes problems with averaging, especially when data availability varies between the members of a group. It can also lead to a high degree of apparent cannibalism which can make it difficult to establish mass balance. These are just some of the potential sources of uncertainty in this published.

For the reasons above it is not possible to fully quantify the uncertainty in the base dataset, but some of the major uncertainties became apparent because of the differences between the base dataset and the balanced (base) model. Furthermore, the scenario exploration, which considers a range of responses, is a form of uncertainty analysis (Hill et al., 2007b), which suggests the range of the potential consequences of krill reduction. A systematic exploration of additional scenarios would be necessary to establish bounds on these potential consequences with confidence.

Even after increasing fish biomass fivefold to balance the model and assuming conservatively that there is no net krill input onto the shelf, $26 \%$ of krill production was still 
unaccounted for. This result merits some discussion of the high P/B value of 2.4 that we used for krill. Krill growth rates are sensitive to temperature, food availability and krill size (Atkinson et al., 2006; 2009) and there is substantial variability in observed krill production rates (Siegel and Nicol, 2000) and considerable uncertainty in annualised extrapolations of these. Our value is based on measurements of daily growth rate at South Georgia (Atkinson et al. 2006) extrapolated over a 4 month growth period. For comparison, a recent circumpolar-scale study derived conservative krill production estimates of 342-536 million tonnes per year, based on a biomass of 379 million tonnes (Atkinson et al., 2009). Previous P/B estimates for krill (Ross and Quetin, 1986; Siegel, 2000) are also lower than our estimate. We consider that an appropriate value for South Georgia is likely to be higher than these wider scale estimates firstly because the South Georgia bloom is the largest in the Antarctic Circumpolar Current and one of the longest lasting, extending for 4-5 months of the year (Atkinson et al., 2001; Korb et al. this issue; Murphy et al., 2007a). Secondly Krill continue to feed throughout the year at South Georgia (Schmidt et al., this issue) with a growth season starting as early as October and probably lasting 6 months (Reid, 2000). The role of advective krill imports is a related issue. The South Georgia shelf is widely considered to be a "semi-open system" where the krill population is not self-replacing but is maintained by a net influx (Atkinson et al. 2001; Gilpin et al. 2002; Shreeve et al. 2005; Tarling et al., 2007; Trathan et al., 1995). Previous studies have compared estimates of krill consumption at South Georgia with estimates of local krill production and either reached the conclusion that consumption is greater than production (Shreeve et al., 2002; Trathan et al., 1995) or standing stock (Boyd and Croxall, 1996; Boyd, 2002; Croxall et al 1984; Croxall and Prince 1987) or conversely that local production is sufficient to support consumption 
500

501

502

503

504

505

506

507

508

509

510

511

512

513

514

515

516

517

518

519

520

521

(Atkinson et al 2001; Gilpin et al 2002). These studies differed both in the methods they

used to extrapolate estimates of production and consumption to greater temporal and spatial scales and the organisms that were included in the suite of consumers. Our study suggests that local krill production is more than adequate to account for known krill consumption. Indeed a much lower P/B value (0.82) would have been sufficient to support the consumption estimate from the base dataset. However, it is possible that there are krill consumers that we have not accounted for (see section 4.2). The relative importance of import versus local production merits further investigation with specific exploration of the uncertainties affecting production, consumption and import estimates. Scenario analysis using a foodweb models, as in this study, is a valuable method for this type of investigation. There are assumptions associated with our scenario exploration. Our switching scenarios imply a competitive hierarchy. Krill predators which are known to include copepods or carnivorous macroplankton in their diets (e.g. diverse flying seabirds) were forced to switch while those which are not (e.g. Antarctic fur seals) were able to consume the krill that switching released. Also, those that fed on both copepods and carnivorous macroplankton (diverse flying seabirds, rock cods, pelagic fish, cephalopods and benthos) took copepods in preference to carnivorous macroplankton. In this case, predators which fed on carnivorous macroplankton but not copepods were able to consume the carnivorous macroplankton that switching released. This was a parsimonious way to implement switching scenarios but there is little information on real competitive hierarchies amongst these organisms. Consequently, the models should not be regarded as reliable predictions of the relative abundance of the different predator groups under change scenarios even 
though the general conclusion that zooplankton production exceeds predator demand in all scenarios remains valid.

The top-down model structure (Steele, 2009) means that it was not necessary to account for the fate of all biomass production to balance the model (Pinkerton et al., 2008). Any production that is not assimilated by predators or explicitly removed as fishery catch or exports is recycled via detritus. Consequently the model does not require expansion of predator biomass in response to the increased zooplankton production in S3 and S4, although this outcome is plausible.

The food value of a biomass unit varies between prey types. Some modellers attempt to overcome this issue by formulating models in terms of a more consistently conserved currency such as organic carbon or energy rather than biomass per se (e.g. Pinkerton et al., 2010). This introduces additional uncertainties when carbon is estimated from biomass, and it does not resolve differences due to the costs of acquiring or digesting prey. Macaroni penguins are able to switch to amphipods when krill are scarce but they ingest less prey wet mass per unit foraging time, and raise smaller offspring (Croxall et al., 1999). This is evidence of a greater cost in foraging time per unit biomass acquired, and might also indicate a lower food value per unit biomass. Our modelling does not distinguish between functional groups on the basis of food value and acquisition costs.

\subsection{Structure and operation of the South Georgia pelagic foodweb}

Notwithstanding the above caveats, Ecopath provides a rational quantitative framework for synthesising voluminous, disparate foodweb data. This provides a powerful tool for assessing and exploring uncertainty. When we assembled the data, it became clear 
that estimates of production by fish are much lower than estimates of consumption of fish.

This corresponds with a previously observed discrepancy between mackerel icefish biomass estimates and potential consumption by fur seals (Reid et al., 2005). The inconsistency could arise because of inaccuracies in any (probably all) of the relevant parameter estimates. Hill et al. (2005) noted that the bottom trawl surveys used in stock assessment are likely to underestimate the abundance of these benthopelagic organisms, which provides support for our approach of adjusting fish biomass to balance the model. Nonetheless this is compelling evidence that the role of fish in the foodweb is poorly understood and merits further investigation.

The EE for primary producers in the base dataset was 1.76, indicating that our estimate of production was only sufficient to meet $57 \%$ of the estimated demand. The shortfall was even more severe (meeting only $46 \%$ of demand) in our increased copepod scenarios. These differences might be greater still if assimilation rates of consumed phytoplankton are less than the assumed $80 \%$. Feeding on primary production accounts for a substantial fraction of the energy transfer in foodwebs ( $40 \%$ of all consumption in our balanced base model). Uncertainty in primary production estimates has important consequences for understanding foodweb properties such as their ability to resist and recover from perturbation and there is a clear need to investigate and reduce this uncertainty. of production. In the base dataset, $60 \%$ of meso and macroplankton production was not explicitly accounted for in the modelled feeding relationships. This fell to $40 \%$ in the base model. In our models this "missing production" enters a general detritus pool and the model 
does not differentiate between the types of non-living organic material consumed by organisms as diverse as bacteria and vertebrate scavengers. Pinkerton et al. (2008) suggest an alternative approach in which it is possible to constrain EE to 1 by explicitly modelling feeding on non-living organic material originating from each group of larger organisms: Scavengers are modelled as predators of the groups which are the source of this material. At present we do not have sufficient information to apply this approach and the low ecotrophic efficiencies highlight the underlying uncertainties and the need for further studies to understand the fate of this "missing production".

The fate of the "missing krill production" is the opposite of the problem suggested by Boyd and Croxall (1996) who calculated that complete replacement of the resident krill stock each month is necessary to satisfy the great demands of the penguins and fur seals. In contrast, our estimate of krill production exceeds our estimate of consumption of krill, suggesting that there may be other sources of mortality in addition to those that we have explicitly modelled. One candidate is high consumption by benthic organisms over the shelf. These organisms might consume either dead and dying krill, injured by surface-layer predators, or krill actively migrating to the seabed to feed. Main et al. (2009) found that krill comprised a large fraction of skate diets, and Schmidt et al. (2011a) found that krill visits to the seafloor were frequent, widespread and an integral part of their biology. There is uncertainty about the extent and importance of benthic predation on krill. The assumption of negligible predation in this study is one of the bounds on this uncertainty whereas a fuller exploration will also need to consider models with high predation. Given the potential importance of bentho-pelagic coupling in ecosystem resilience, this issue warrants further study. 

range of predators. Croxall et al. (1984) considered birds that nest at South Georgia, and krill consumption across their entire foraging range during chick rearing. They identified macaroni penguins as the main krill consumers nesting at South Georgia with the members of our diverse flying seabirds second and gentoo penguins third. Hill et al. (2007a) included fish in their data compilation for a selection of important krill consumers at the Scotia Sea and Antarctic Peninsula scale. This compilation excluded flying seabirds, which were the main krill consumers on the South Georgia shelf in the base dataset. Hill et al. (2007a) suggested that, at the regional scale, fish consume more krill than baleen whales, penguins, and fur seals combined but that around South Georgia (within $126 \mathrm{~km}$ of the coast) penguins were the main krill consumers, followed, in descending order of importance, by fur seals, demersal fish, pelagic fish, and whales.

The discrepancies between these studies and our own arise largely from the different scales considered, and the omission of significant consumers in previous studies. This highlights the current lack of comprehensive assessments of foodweb structure at the various scales that ecosystem models need to consider (Hill et al., 2006, 2007b). Although diverse flying birds apparently obtain $81 \%$ of their diet from off-shelf areas compared to $25 \%$ for macaroni penguins, the greater biomass of the former means that they are more important on-shelf krill consumers. Antarctic fur seals were also more important than macaroni penguins due to both a higher overall consumption and more on-shelf feeding. The balanced model presents a very different view of krill consumption due to the revised fish biomass needed to match estimates of fish consumption. This raises the possibility that 
613 fish might, in fact, be more important krill consumers than the air breathing vertebrates that

614 have dominated previous studies.

615 The data compilation suggests that copepods are potentially more significant

616 consumers of primary production and producers of biomass than krill. This was also the

617 conclusion of Shreeve et al. (2005), whose estimates of copepod production we included in

618 the base data. Many of South Georgia's vertebrates feed mainly on krill and are affected by

619 fluctuations in its availability (Croxall et al., 1997; Everson et al., 1997; Main et al., 2009;

620 Reid \& Arnould, 1996; Reid \& Forcada, 2005; Shreeve et al., 2009). Production estimates

621 suggest that there is abundant alternative biomass in copepods and their consumers.

622 However, observations suggest that, in the short term at least, predators are not able to

623 efficiently exploit this alternative biomass. It is currently unknown whether predator

624 behaviour could adapt over the longer term to exploit alternative prey types.

The scenario exploration suggests that copepod biomass production exceeds the feeding requirements of upper trophic level predators in this ecosystem. Our switching scenarios required a substantial replacement of krill in predator diets with much smaller copepods. It was not possible to maintain predator biomass using larger alternative prey (fish and macroplankton) alone, as these food sources were fully utilised $(E E=1)$. Predators could therefore be severely impacted by a plausible decline in krill biomass if they are not able to efficiently exploit copepods. copepod biomass is only possible if primary production is not limiting. Nonetheless this 
consumption by predators. Indeed this production, even with an $80 \%$ reduction in krill biomass, exceeds all modelled secondary consumption including off-shelf feeding. The integration of many previous studies gives an indication of the role of each predator group in the foodweb as a whole, which is summarised in the group's trophic level. Stowasser et al. (this issue) used stable isotope analysis to estimate the trophic levels of a range of organisms in the wider Scotia Sea ecosystem and comparison of the two studies provides a level of cross-validation. Trophic levels for comparable taxa were (simple average of Stowasser et al. this issue estimates, followed by our base data estimate): fur seals 3.9, 3.9; gentoo penguins 3.9, 4.2; macaroni penguins 4.0, 4.3; chinstrap penguins 3.5, 4.0; blackbrowed albatross 4.8, 4.2; grey-headed albatross 4.8, 3.9; predatory seabirds 5.2, 3.8; diverse flying birds 3.8, 3.5; pelagic fish 4.1, 4.2; cephalopods 3.7, 4.1; krill 2.5, 2.7; carnivorous macroplankton 3.2, 3.4; copepods 2.7, 2.8; salps 2.0, 2.8. There was reasonable agreement between the two studies, although there were significant discrepancies for most bird groups, especially predatory seabirds. The Stowasser et al. (this issue) estimate for predatory seabirds is consistent with the other apex predators in our study, suggesting that our estimate is not representative of this taxon. $80 \%$ of the diet of predatory seabirds was imports. This highlights a weakness in Ecopath based estimates of trophic levels for groups, including most of our bird groups, foraging outside the model arena. The stable isotope study also provides some guidance for revision of our functional groups. For example, we included Themisto gaudichaudii in carnivorous macroplankton whereas the trophic level estimated by Stowasser et al. (this issue) suggests that this species is functionally more similar to herbivorous zooplankton. 

current knowledge that warrant further exploration. There is a need to better understand zooplankton dynamics at interannual timescales, as the response of the zooplankton foodweb to change will determine effects on the higher trophic levels. As discussed above, the plausibility of the scenarios depends to some extent on the ability of predators to switch between zooplankton prey and maintain previous levels of production per unit consumption. It also depends on whether an increase in copepod production would be limited by available primary production. More information on diet flexibility and its consequences would be useful for predicting future dynamics. Finally, the prevalence of offshelf feeding highlights the strong levels of ecological connectivity between areas and the somewhat arbitrary nature of a geographical definition of the foodweb. Future model development should consider the consequences of this connectivity.

\section{ACKNOWLEDGEMENTS} indebted to the large group of experts listed in the SI for sharing their knowledge of Southern Ocean ecology. In particular we thank Keith Reid for his support and input during the early stages of this project, and Steve Mackinson for valuable clarification and guidance. We also thank Peter Fretwell, Sui Phang, Stella Deakin and Nadine Johnston for specific assistance with the data and Tosca Ballerini and Matt Pinkerton for constructive comments. 
Atkinson A., 1994. Diets and feeding selectivity among the epipelagic copepod community near South Georgia in summer. Polar Biology 14, 551-560

Atkinson A., 1995. Omnivory and feeding selectivity in five copepod species during spring in 684 the Bellingshausen Sea, Antarctica. ICES Journal of Marine Science 52, 385-396

Atkinson A., 1998. Life cycle strategies of epipelagic copepods in the Southern Ocean. Journal of Marine Systems 15, 289-311

Atkinson A, Shreeve RS, 1995. Response of the copepod community to a spring bloom in the

Bellingshausen Sea. Deep-Sea Research 42, 1291-1311

Atkinson A, Shreeve RS, Pakhomov EA, Priddle J, Blight SP, Ward P, 1996. Zooplankton response to a spring bloom near South Georgia, Antarctica. Marine Ecology Progress Series $144,195-210$

Atkinson A, Shreeve RS, Tarling GA, Hirst AG, Rothery P, Pond D, Korb R, Murphy EJ, Watkins 693

JL, 2006. Natural growth rates of Antarctic krill (Euphausia superba): II. Predictive models based on food, temperature, body length, sex, and maturity stage. Limnology and Oceanography 51, 973-987

Atkinson A, Siegel V, Pakhomov EA, Rothery P, Loeb V, Ross RM, Quetin LB, Fretwell P, Antarctic krill. Mar Ecol Prog Ser 362, 1-23 
Georgia, Antarctica, II. Euphausia superba as a major control on copepod abundance.

Atkinson A, Ward P, Williams $R$, Poulet $S A, 1992$. Feeding rates and diel vertical migration of copepods near South Georgia: comparison of shelf and oceanic sites. Marine Biology $114: 49-56$

Atkinson A, Whitehouse MJ, 2001. Ammonium regeneration by Antarctic mesozooplankton: an allometric approach. Marine Biology 139:301-311

Atkinson A., Peck J.M., 1988. A summer-winter comparison of zooplankton in the oceanic area around South Georgia. Polar Biology 8:463-473

Atkinson A., Peck J.M., 1990. The distribution of zooplankton in relation to the South Georgia shelf in summer and winter. In: Kerry KR, Hempel G, eds.. Antarctic Ecosystems. Ecological change and Conservation. Springer Verlag, Berlin pp 159-165

Atkinson A., Schmidt K., Fielding S., Kawaguchi S., Geissler P, 2011. Variable food absorption by Antarctic krill: relationships between diet, egestion rate and the composition and sinking rates of their fecal pellets. Deep-Sea Research II. This issue

Atkinson, A., Siegel, V., Pakhomov, E.A. Jessopp, M.J., Loeb, V., 2009. A re-appraisal of the total biomass and annual production of Antarctic krill. Deep Sea Research Part I: 56, 727740. increase in salps within the Southern Ocean. Nature 432, 100-103 
Atkinson, A., Ward, P., Hill, A., Brierley, A. S., Cripps, G. C. , 1999. Krill-copepod interactions at South Georgia, Antarctica, II. Euphausia superba as a major control on copepod abundance Marine Ecology Progress Series 176, 63-79 (doi:10.3354/meps176063) Atkinson, A., Whitehouse, M.J., Priddle, J., Cripps, G.C, Ward, P. Brandon, M.A., 2001. South Georgia, Antarctica: a productive, cold water, pelagic ecosystem. Marine Ecology-Progress

727 Series 216, 279-308.

Boyd I.L., Croxall, J.P., 1996. Preliminary estimates of krill consumption by Antarctic fur seals and macaroni penguins at South Georgia. Document WG-EMM-96/65. CCAMLR, Hobart.

$73019 p p$

Boyd, I.L. 2002. Estimating food consumption of marine predators: Antarctic fur seals and macaroni penguins. Journal of Applied Ecology 39, 103-119.

CCAMLR, 2011. Statistical Bulletin Volume 23, 2001 -2010). CCAMLR, Hobart 293pp.

Christensen, V. and C. J. Walters. 2004. Ecopath with Ecosim: methods, capabilities and limitations. Ecol. Model. 172:109-139

Christensen, V. and D. Pauly. 1992. The ECOPATH II - a software for balancing steady-state ecosystem models and calculating network characteristics. Ecological Modelling 61: 169185.

Croxall, J. P., Ricketts, C. Prince, P. A., 1984. Impact of seabirds on marine resources, especially krill, of South Georgia waters. Seabird Energetics, eds. G. C. Whittow and A. Rahn), pp. 285-318. Plenum, New York. 

behaviour in relation to vertical distribution of krill. Journal of Animal Ecology 54: 1-8.

744 Croxall, J.P., Prince, P.A., 1987. Seabirds as predators on marine resources, especially krill, at South Georgia, in J.P. Croxall (ed) Seabirds: feeding ecology and role in marine ecosystems.

746 Cambridge University Press, Cambridge. pp347-364

747 Croxall, J.P., Prince, P.A., Reid, K., 1997. Dietary segregation of krill-eating South Georgia 748 seabirds. Journal of Zoology 242: 531-556 (DOI: 10.1111/j.1469-7998.1997.tb03854.x)

749 Croxall, J.P., Reid, K., Prince, P. A., 1999. Diet, provisioning and productivity responses of 750 marine predators to differences in availability of Antarctic krill. Marine Ecology Progress 751 Series 177: 115-131.

752 Everson, I., Kock K.-H., Parkes, G., 1997. Interannual variation in condition of the mackerel 753 icefish. Journal of Fish Biology. 51, 146-154.

754 Gilpin, L.C., Priddle, J., Whitehouse, M.J., Savidge, D., Atkinson, A. 2002. Primary production 755 and carbon uptake dynamics in the vicinity of South Georgia-balancing carbon fixation and 756 removal. Marine Ecology Progress Series, 242: 51-62. Hewitt, R.P., Watkins, J., Naganobu, M., Sushin, V., Brierley, A.S., Demer, D., Kasatkina, S., Takao, Y., Goss, C., Malyshko, A., Brandon, M., Kawaguchi, S., Siegel, V., Trathan, P., Emery, J., Everson, I., \& Miller, D., 2004. Biomass of Antarctic krill in the Scotia Sea in January/February 2000 and its use in revising an estimate of precautionary yield. Deep-Sea Research Part II -Topical Studies in Oceanography, 51: 1215-1236. 
762

763

764

765

766

767

768

769

770

771

772

773

774

775

776

777

778

779

780

Hill S.L., Murphy E. J., Reid K., Trathan P. N., Constable, A. J., 2006. Modelling Southern Ocean ecosystems: krill, the food-web, and the impacts of harvesting. Biological Reviews, 81: 581-608 (DOI: 10.1017/S1464793106007123)

Hill, S. L., Reid, K. and North, A. W., 2005. Recruitment of mackerel icefish, Champsocephalus gunnari at South Georgia indicated by predator diets and its relationship with sea surface temperature. Canadian Journal of Fisheries and Aquatic Sciences 62(11), $2530-2537$.

Hill, S.L., Reid, K., Thorpe, S.E., Hinke, J., Watters, G.M. , 2007a. A compilation of parameters for ecosystem dynamics models of the Scotia Sea - Antarctic Peninsula region. CCAMLR Science 14: 1-25.

Hill, S.L., Watters, G.M., Punt, A.E., McAllister, M.K., LeQuere, C., Turner, J., 2007b. Model uncertainty in the ecosystem approach to fisheries. Fish and Fisheries, 8, 315-33

Hopkins T.L., Ainley D.G., Torres J.J., Lancraft T.L., 1993a. Trophic structure in open waters of the marginal ice zone in the Weddell-Scotia confluence region during spring, 1983). Polar Biol 13:389-397

Hopkins T.L., Lancraft T.M., Torres J.J., Donelley J, 1993b. Community structure and trophic ecology of zooplankton in the Scotia Sea marginal ice zone in winter, 1988). Deep Sea Res 40:81-105

Hopkins T.L., Torres J.J., 1988. The zooplankton community in the vicinity of the ice edge, western Weddell Sea, March 1986. Polar Biol 9:93-106 
Kavanagh, P, Newlands, N., Christensen, V., Pauly, D., 2004. Automated parameter optimization for Ecopath ecosystem models, Ecol. Model. 172:141-149.

Korb R.E., Whitehouse M.J., Ward P., Gordon M., Venables H.J. , 2011. Regional and seasonal differences in microplankton biomass, productivity and structure across the Scotia Sea and implications for the export of biogenic carbon. Deep Sea Research II. This issue Mackey AP, Atkinson A, Hill SL, Ward P, Cunningham NJ, Johnston NM, Murphy EJ, 2011. Antarctic macrozooplankton of the southwest Atlantic sector and Bellingshausen Sea: baseline historical, Discovery Investigations, 1928-1935. distributions related to temperature and food, with projections for subsequent ocean warming. Deep Sea Research II. This issue

Main, C.E., Collins, M.A., Mitchell, R. Belchier, M., 2009. Identifying patterns in the diet of mackerel icefish, Champsocephalus gunnari. at South Georgia using bootstrapped confidence intervals of a dietary index. Polar Biology. 32, 569-581 (doi: 10.1007/s00300008-0552-7)

Murphy, E. J., J. L. Watkins, et al., 2007a. Spatial and temporal operation of the Scotia Sea ecosystem: a review of large-scale links in a krill centred food web. Philosophical Transactions of the Royal Society B-Biological Sciences 362(1477), 113-148.

Murphy, E.J., Morris, D.J., Watkins, J.L., Priddle, J., 1988. Scales of interaction between Antarctic krill and the environment. In: Antarctic Ocean and Resources Variability. D. Sahrhage, ed.). Berlin: Springer-Verlag, pp. 120-130.

Murphy, E.J., Trathan, P.N., Watkins, J.L., Reid, K., Meredith, M.P., Forcada, J., Thorpe, S.E., Johnston, N.M., Rothery, P., 2007b. Climatically driven fluctuations in Southern Ocean 
Murphy, E.J., Watkins, J.L., Meredith, M.P., Ward, P., Trathan, P.N., Thorpe, S.E., 2004.

Southern Antarctic Circumpolar Current Front to the northeast of South Georgia: Horizontal advection of krill and its role in the ecosystem. Journal of Geophysical Research 109:

North AW, Ward P, 1989. Initial feeding by Antarctic fish larvae during winter at South

812 North AW, Ward P, 1990. The feeding ecology of larval fish in an Antarctic fjord, with emphasis on Champsocephalus gunneri. In: Kerry KR, Hempel G, eds. Antarctic Ecosystems.

814 Ecological Change and Conservation, Springer-Verlag Berlin p 299-307

$815 \emptyset$ resland V, 1990. Feeding and predation impact of the chaetognath Eukrohnia hamata in 816 Gerlache Strait, Antarctic Peninsula. Marine Ecology Progress Series 63, 201-209.

$817 \varnothing$ resland V, Ward P, 1993. Summer and winter diet of four carnivorous copepod species around South Georgia. Mar Ecol Prog Ser 98:73-78

Pakhomov EA, Perissinotto R, 1996. Trophodynamics of hyperiid amphipod Themisto gaudichaudii in the South Georgia region during late austral summer. Mar Ecol Prog Ser $134: 91-100$ 
Pakhomov EA, Verhaye HM, Atkinson A, Laubscher RK, Taunton-Clark J, 1997b. Structure and grazing impact of the mesozooplankton community during late summer 1994 near South Georgia, Antarctica. Polar Biology 18:180-192

Pakhomov, E.A., Dubischar, C.D., Strass, V., Brichta, M., Bathmann, U.V. 2006. The tunicate Salpa thomposoni ecology in the Southern Ocean. I. Distribution, biomass, demography and feeding ecophysiology. Marine Biology 149, 609-623.

Palomares, M.L., Pauly, D., 1989. A multiple regression model for prediction the food consumption of Marine Fish populations. Australian Journal of Marine and Freshwater Research 40, 259 - 273, (doi:10.1071/MF9890259)

Pinkerton, M.H., Bradford-Grieve, J.M., Hanchet., S.M. 2010. A balanced model of the food web of the Ross Sea, Antarctica. CCAMLR Science, 17: 1-31.

Pinkerton, M.H., Lundquist, C.J., Duffy, C.A.J,. Freeman D.J., 2008. Trophic modelling of a New Zealand rocky reef ecosystem using simultaneous adjustment of diet, biomass and energetic parameters. Journal of Experimental Marine Biology and Ecology. 367: 189-203

Priddle J, Leakey R, Symon C, Whitehouse M, Robins D, Cripps G, Murphy E, Owens N, 1995. Nutrient cycling by Antarctic marine microbial plankton. Mar Ecol Prog Ser 116:181-198

Reid K. and Arnould J. P. Y. , 1996. The diet of Antarctic fur seals Arctocephalus gazella during the breeding season at South Georgia. Polar Biology 16: 105-114, DOI: 10.1007/BF02390431) 
Reid, K. and J. P. Croxall, 2001. Environmental response of upper trophic-level predators reveals a system change in an Antarctic marine ecosystem. Proceedings of the Royal Society of London Series B-Biological Sciences 268(1465): 377-384.

Reid, K., 2000. Growth of Antarctic krill Euphausia superba at South Georgia. Marine Biology $138,57-62$.

Reid, K., Forcada, J., 2005. Causes of offspring mortality in the Antarctic fur seal, Arctocephalus gazella: the interaction of density dependence and ecosystem variability. Canadian Journal of Zoology, 83:604-609, 10.1139/z05-045

Reid, K., Hill, S. L., Diniz, T. C. D. and Collins, M. A., 2005. Mackerel icefish Champsocephalus gunnari in the diet of upper trophic level predators at South Georgia: implications for fisheries management. Marine Ecology Progress Series 305: 153-161.

Reilly, S. Hedley, S., Borberg, J., Hewitt, R., Thiele, D., Watkins, J. Naganobu, M., 2004. Biomass and energy transfer to baleen whales in the South Atlantic sector of the Southern Ocean. Deep Sea Research Part II: Topical Studies in Oceanography Volume 51: 1397-1409.

Ross, R.M., Quetin, L. 1986. How productive are Antarctic Krill? Bioscience 36, 264-269.

Schmidt K, Atkinson A, Petzke K-J, Voss M, Pond, DW, 2006. Protozoans as a food source for Antarctic krill, Euphausia superba: complementary insights from stomach content, fatty acids, and stable isotopes. Limnology and Oceanography 51: 2409-2427

Schmidt K, Atkinson A, Steigenberger S, Fielding S, Lindsay MCM, Pond DW, Tarling GA, Klevjer TA, Allen CS, Nicol S, Achterberg EP, 2011a. Seabed foraging by Antarctic krill: 
864

865

866

867

868

869

870

871

872

873

874

875

876

877

878

879

880

881

882

883

884

Implications for stock assessment, bentho-pelagic coupling and the vertical transfer of iron.

Limnology and Oceanography 56, 1411-1428.

Schmidt K, Atkinson A, Venables HJ, Pond DW, 2011. Early spawning of Antarctic krill in the Scotia Sea is fuelled by "superfluous feeding" on non-ice-associated phytoplankton blooms. Deep-Sea Research II. This issue.

Shreeve RS, Tarling GA, Atkinson A, Ward P, Goss C, Watkins JL., 2005. Relative production of Calanoides acutus (Copepoda: Calanoida) and Euphausia superb (Antarctic krill) at South Georgia, and its implications at wider scales. Marine Ecology Progress Series 298: 229-239

Shreeve, R., M. Collins, Tarling, G.A., Main, C.E., Ward, P., Johnston, N.M., 2009. Feeding ecology of myctophid fishes in the northern Scotia Sea. Marine Ecology Progress Series 386: 221-236.

Shreeve, R.S., Ward, P., Whitehouse, M.J. 2002. Copepod growth and development around South Georgia: relationships with temperature, food and krill. Marine Ecology Progress Series. 233: 169-183.

Siegel, V. 2000. Krill, Euphausiacea. life history and aspects of population dynamics. Canadian Journal of Fisheries and Aquatic Sciences 57, 130-150.

Siegel, V., Loeb, V., 1995. Recruitment of Antarctic krill Euphausia superba and possible causes for its variability. Marine Ecology Progress Series. 123, 45-56 (doi:10.3354/meps123045).

Siegel, V., Nicol, S. 2000. Population parameters, in: Everson, I. (Ed), Krill Biology Ecology \& Fisheries. Blackwell, Oxford, pp: 103-149. 
885

886

887

888

889

890

891

892

893

894

895

896

897

898

899

900

901

902

903

904

905

Steele JH, 2009. Assessment of some linear food web methods. Journal of Marine Systems 76: 186-194, doi:10.1016/j.jmarsys.2008.05.012)

Stowasser G, McGill RAR, Atkinson A, Phillips RA, Collins MA, Pond DW, 2011. Food web dynamics in the Scotia Sea in summer: a stable isotope study. Deep-Sea Research II. This issue.

Straile, D. 1997. Gross growth efficiencies of protozoan and metazoan zooplankton and their dependence on food concentration, predator-prey weight ratio, and taxonomic group. Limnology and Oceanography 42, 1375-1385.

Tarling GA, Cuzin-Roudy J, Thorpe SE, Shreeve RS, Ward P, Murphy EJ, 2007. Recruitment of Antarctic krill Euphausia superba in the South Georgia region: adult fecundity and the fate of larvae. Marine Ecology Progress Series 331:161-179

Trathan, P. N.; Everson, I.; Miller, D. G. M.; Watkins, J. L.; Murphy, E. J. 1995. Krill biomass in the Atlantic. Nature, 373, 201-202.

Trivelpiece, W.Z., Hinke, J.T., Miller, A.K., Reiss, C.S., Trvelpiece, S.G., Watters, G.M. 2011. Variability in krill biomass links harvesting and climate warming to penguin population changes in Antractica. Proceedings of the National Academy of Science 108, 7625-7628. von Harbou, L., Dubischar, C.D., Pakhomov, E.A., Hunt, B.P.V., Hagen. W., Bathmann, U.V., in press. Salps in the Lazarev Sea, Southern Ocean: I. Feeding dynamics. Marine Biology.

Ward P, Atkinson A, Murray AWA, Wood AGW, Williams R, Poulet SA, 1995. The summer zooplankton community at South Georgia: biomass, vertical migration and grazing. Polar Biology 15:195-208 
Ward P, Atkinson A, Tarling GA, in review. Mesozooplankton community structure and variability in the Scotia Sea: a seasonal comparison. Deep-Sea Res II

C, Cunningham N, 2005. Phyto- and zooplankton community structure and production around South Georgia, Southern Ocean. during summer 2001/2002. Deep-Sea Research I: 52: $421-441$

Ward P, Shreeve R.S. 1999. The spring mesozooplankton community at South Georgia: a comparison of shelf and oceanic sites. Polar Biology22, 289-301.

Ward P, Shreeve RS, Atkinson A, Korb R, Whitehouse MJ, Thorpe S, Pond D, Cunningham N., 2006. Plankton community structure and variability in the Scotia Sea: austral summer 2003.

917 Ward, P. 1985. On the biology of Antarctomysis ohlini, Crustacea: Mysidacea. at South 918 Georgia. British Antarctic Survey Bulletin 67, 13-23.

919 Ward, P. 1990. The distribution of zooplankton in an Antarctic fjord at South Georgia during 920 summer and winter. Antarctic Science 1, 141-150.

921 Ward, P., Shreeve, R.S., Tarling, G.A. 2006. The autumn mesozooplankton community at 922 South Georgia: biomass, population structure and vertical distribution.

923 Watts J, Tarling GA, 2011. Population dynamics and production of Themisto gaudichaudii, 924 Amphipoda, Hyperiidae at South Georgia, Antarctica. Deep Sea Research II. This issue. 
925 Whitehouse MJ, Atkinson A, Rees AP, 2011a. Close coupling between ammonium uptake by

926 phytoplankton and excretion by Antarctic krill, Euphausia superba. Deep-Sea Research I 58,

927 issue $7,725-732$

928 Whitehouse MJ, Atkinson A, Ward P, Korb RE, Rothery P, Fielding S, 2009. Role of krill versus

929 bottom-up factors in controlling phytoplankton biomass in the northern Antarctic waters of

930 South Georgia. Marine Ecology Progress Series 393, 69-82

931 Whitehouse, M.J., Meredith, M.P., Rothery, P., Atkinson, A., Ward, P., Korb, R.E., 2008.

932 Rapid warming of the ocean around South Georgia, Southern Ocean, during the 20th

933 century: Forcings, characteristics and implications for lower trophic levels. Deep Sea

934 Research Part I: Oceanographic Research Papers 55, 1218-1228.

935 Whitehouse, MJ, Atkinson A, Korb RE, Venables HJ, Pond DW, Gordon M, in press.

936 Substantial primary production in the land-remote region of the central and northern Scotia 937 Sea. Deep-Sea Res II. This issue. 
TABLE 1: Base data values for krill and zooplankton groups for the South Georgia shelf system. Abbreviations introduced in this table: DM = dry mass, WM = wet mass, C = carbon, SG = South Georgia, GGE = gross growth efficiency, defined as growth divided by ingestion, chl = chlorophyll. We consistently converted dry mass to wet mass using a conversion factor of 4 . We also consistently used a GGE estimate of 25\% (Straile 1997). The exact meaning of a measured growth rate can vary depending on the methodology used, which is why we used either simple or compound scaling depending on the details. In either case the resulting production value was compared with a value derived from consumption and GGE to ensure consistency. Scaling of daily values by growing season was achieved by multiplying the daily value by $365 *$ (growing season in months)/12.

\begin{tabular}{|c|c|c|c|c|}
\hline Group & Biomass (B: $g$ wet mass $\mathrm{m}^{-2}$ ) & $\begin{array}{l}\text { Annual production/mean biomass } \\
(\mathrm{P} / \mathrm{B})\end{array}$ & $\begin{array}{l}\text { Annual consumption/ mean } \\
\text { biomass }(Q / B)\end{array}$ & Diet \% composition \\
\hline $\begin{array}{l}\text { ZKR (Euphausia } \\
\text { superba) }\end{array}$ & $\begin{array}{l}32.71 \\
\text { Based on a synoptic krill } \\
\text { survey in } 2000 \text { (Hewitt et al. } \\
\text { 2004) which produced } \\
\text { coastal and oceanic } \\
\text { estimates of krill biomass } \\
\text { density at South Georgia } \\
\text { using the Stochastic } \\
\text { distorted wave Born } \\
\text { approximation methodology } \\
\text { (BAS unpublished data). This } \\
\text { is the average of those two } \\
\text { values weighted by the } \\
\text { proportion of the modelled } \\
\text { area that fell into the two } \\
\text { survey strata }\end{array}$ & $\begin{array}{l}\text { 2.4 } \\
\text { Compound mean daily mass growth } \\
\text { rate(1.024\% per day) at low and high } \\
\text { summer chl } a \text { sites at South Georgia } \\
\text { (Table } 7 \text { of Atkinson et al. 2006), over a } \\
4 \text { month growing The assumption of a } \\
4 \text { month growing season is } \\
\text { conservative, based on unpublished } \\
\text { seasonal fisheries-derived data by } \\
\text { Atkinson (growth), and published data } \\
\text { in Reid (2000) (growth) and Schmidt et } \\
\text { al. (this issue) (feeding at South } \\
\text { Georgia occurs year-round). }\end{array}$ & $\begin{array}{l}9.6 \\
\text { P/B / GGE of } 25 \% \text { (Straile 1997). } \\
\text { This value fits well with a daily C } \\
\text { ration of } 5 \% \text { measured by } \\
\text { Pakhomov et al. (1997a) at South } \\
\text { Georgia in summer, if this rate is } \\
\text { sustained for half of the year. }\end{array}$ & $\begin{array}{l}\text { ZCA 0.5, ZHE 0.5 ZCO 2.0, ZHT 45, } \\
\text { PHY 42, DET } 10 \\
\text { Based on volumetric gut content } \\
\text { analysis from } 16 \text { krill on SG shelf in } \\
\text { summer bloom (Schmidt et al. 2006), } \\
\text { and finding of important role of } \\
\text { benthic feeding on detritus (Schmidt } \\
\text { et al. 2011a) Note that seabed- } \\
\text { derived phytodetritus component is } \\
\text { included in PHY group here. } \\
\text { Metazoan contribution is based } \\
\text { mainly on volumetric analysis of krill } \\
\text { stomachs from Scotia Sea in spring } \\
\text { (Schmidt et al. this issue). } \\
\text { Importance of non-phytoplankton } \\
\text { food at South Georgia supported by } \\
\text { Atkinson and Snyder (1997) and } \\
\text { Pakhomov et al. (1997a). }\end{array}$ \\
\hline $\begin{array}{l}\text { ZCA (Carnivorous } \\
\text { macroplankton: } \\
\text { amphipods, } \\
\text { chaetogantahs, }\end{array}$ & $\begin{array}{l}8.4 \\
\text { Mean DM of } 2.1 \mathrm{~g} \mathrm{~m}^{-2} \text { based } \\
\text { on } 3 \text { mainly summer studies } \\
\text { (Ward 1990, Atkinson et al. }\end{array}$ & $\begin{array}{l}\text { 4.87 } \\
\text { Based on growth rates measured on } \\
\text { dominant amphipod Themisto } \\
\text { gaudichaudii on inner SG shelf by }\end{array}$ & $\begin{array}{l}19.5 \\
\text { Based on the production values } \\
\text { and a GGE of } 25 \% \text { (Straile 1997). } \\
\text { Alternatively based on a daily }\end{array}$ & $\begin{array}{l}\text { ZCO 54, ZHE 15, ZSA 1, ZHT 10, PHY } \\
\text { 10, DET } 10 \\
\text { Based on SG diet data for Themisto } \\
\text { gaudichaudii and carnivorous }\end{array}$ \\
\hline
\end{tabular}




\begin{tabular}{|c|c|c|c|c|}
\hline $\begin{array}{l}\text { small euphausiids, } \\
\text { fish larvae, mysids, } \\
\text { large predatory } \\
\text { copepods such as } \\
\text { Euchaeta spp.) }\end{array}$ & $\begin{array}{l}\text { 1996, Pakhomov et al. } \\
\text { 1997b). Biomass assumed } \\
\text { essentially constant } \\
\text { throughout season based on } \\
\text { winter survey data (Atkinson } \\
\text { et al. 1988, Atkinson and } \\
\text { Peck 1990) }\end{array}$ & $\begin{array}{l}\text { Watts and Tarling (in press, this } \\
\text { volume) which gives daily mean P/B of } \\
0.0133 \text { multiplied by } 365 \text { to represent } \\
\text { a } 12 \text { month growing sea. The P/B for } \\
\text { mysids also exceeds the value for krill } \\
\text { at South Georgia. (Ward 1985). }\end{array}$ & $\begin{array}{l}\text { carbon ration of } 7.1 \% \text { (for } \\
\text { Themisto gaudichaudii in summer } \\
\text { at SG; Pakhomov and Perssinotto, } \\
\text { 1996) the value would be } 25.9, \\
\text { assuming a year-round growing } \\
\text { season. This broadly supports the } \\
\text { estimate given. }\end{array}$ & $\begin{array}{l}\text { copepods and fish larvae (Pakhomov } \\
\text { and Perissinotto 1996, Øresland and } \\
\text { Ward 1993, North and Ward 1989, } \\
\text { 1990), plus diet and trophic level } \\
\text { data for Antarctic chaetognaths, } \\
\text { small euphausiids in Scotia sector } \\
\text { (Øresland 1990, Hopkins and Torres } \\
\text { 1988, Hopkins et al. 1993a,b, } \\
\text { Stowasser et al. in review, this } \\
\text { volume) }\end{array}$ \\
\hline $\begin{array}{l}\text { ZHE (Mainly } \\
\text { herbivorous non- } \\
\text { copepod } \\
\text { mesozooplankton: } \\
\text { pteropods, } \\
\text { ostracods, } \\
\text { appendicularians, } \\
\text { and meroplankton } \\
\text { of benthic } \\
\text { organisms) }\end{array}$ & $\begin{array}{l}6.9 \\
\text { Mean total } \\
\text { mesozooplankton biomass is } \\
8.63 \text { g DM m}{ }^{-2} \text {, based on } 7 \\
\text { studies (Ward et al. , 1995, } \\
\text { 2006, Ward and Shreeve, } \\
\text { 1999, Atkinson et al. 1996, } \\
\text { Atkinson \& Whitehouse } \\
\text { 2001, Pakhomov et al. } \\
\text { 1997b). } \\
\text { ZHE comprises } 20 \% \text { of this, } \\
\text { based on Atkinson et al. } \\
\text { (1996), Ward \& Shreeve } \\
\text { (1999), remainder being } \\
\text { copepods. Winter biomass is } \\
\text { similar to that in summer } \\
\text { (Atkinson and Peck 1990). }\end{array}$ & $\begin{array}{l}8.6 \\
\text { In absence of other data we used the } \\
\text { ZCO P/B as below. }\end{array}$ & $\begin{array}{l}34 \\
\text { In the absence of SG grazing data } \\
\text { across the non-copepod } \\
\text { herbivores their Q/B is derived } \\
\text { from the P/B and a GGE of } 0.25 \\
\text { (Straile 1997) }\end{array}$ & $\begin{array}{l}\text { PHY } \mathbf{4 0 ,} \text { ZHT 50, BACT } \mathbf{8 , ~ D E T ~} 2 \\
\text { In the absence of SG grazing data } \\
\text { across the non-copepod herbivores } \\
\text { their diets are assumed the same as } \\
\text { that of the ZCO (see below) }\end{array}$ \\
\hline $\begin{array}{l}\text { ZCO (Copepods that } \\
\text { are mainly small } \\
\text { particle feeders) for } \\
\text { example } \\
\text { Rhincalanus gigas, } \\
\text { Calanoides acutus, } \\
\text { Calanus propinquus, }\end{array}$ & $\begin{array}{l}\mathbf{2 7 . 6} \\
\text { See row above for source of } \\
\text { this value }\end{array}$ & $\begin{array}{l}8.6 \\
\text { This is based on a P/B for stages CIV } \\
\text { and CV of Calanoides acutus, a } \\
\text { biomass-dominant copepod measured } \\
\text { during } 2001 / 2002 \text { summer by Shreeve } \\
\text { et al. (2005). This daily P/B estimate (in } \\
\text { C) of } 0.0566 \text { was scaled to an annual }\end{array}$ & $\begin{array}{l}34 \\
\mathrm{Q} / \mathrm{B} \text { is derived from the } \mathrm{P} / \mathrm{B} \text { and a } \\
\mathrm{GGE} \text { of } 0.25 \text { (Straile 1997). This } \\
\text { corresponds to a daily } \mathrm{C} \text { ration of } \\
22 \% \text { sustained over a period of } 5 \\
\text { months where chl } a \text { levels at SG } \\
\text { are }>1 \mathrm{mg} \mathrm{m}^{-3} \text { (see } \mathrm{P} / \mathrm{B} \text { column). }\end{array}$ & $\begin{array}{l}\text { PHY 40, ZHT 50, BACT 8, DET } 2 \\
\text { Based on study at SG and } \\
\text { Bellingshausen on major species of } \\
\text { both large and small copepods } \\
\text { (Atkinson 1994, 1995, Atkinson and } \\
\text { Shreeve 1995). Diatoms comprised } \\
39 \text { and 49\% of identified food C, }\end{array}$ \\
\hline
\end{tabular}




\begin{tabular}{|c|c|c|c|c|}
\hline $\begin{array}{l}\text { C. simillimus, } \\
\text { Metridia spp. } \\
\text { Ctenocalnus spp. } \\
\text { Microcalanus spp., } \\
\text { Oithona spp., } \\
\text { Oncaea spp. }\end{array}$ & & $\begin{array}{l}\text { value assuming a growing season of } 5 \\
\text { months, based on the period when } \\
\text { mean chl a concentration is at bloom } \\
\text { levels of }>1 \mathrm{mg} \mathrm{m}^{-3} \text { at South Georgia } \\
\text { (Whitehouse et al. in review, this } \\
\text { volume). This is also the period in } \\
\text { which the biomass-dominants are in } \\
\text { the upper water layers (Atkinson 1998) }\end{array}$ & $\begin{array}{l}\text { This ration is within the range } \\
\text { measured for a range of copepod } \\
\text { sizes at SG (Atkinson et al. 1992, } \\
\text { Atkinson 1994) }\end{array}$ & $\begin{array}{l}\text { remainder being motile, mainly } \\
\text { members of ZHT group. Importance } \\
\text { of motile taxa to diets of many } \\
\text { species supported by SG study of } \\
\text { Atkinson et al. (1996). We ascribed a } \\
\text { nominal 10\% to detritus colonised by } \\
\text { bacteria, a known food for Oncaea } \\
\text { sppandOithona spp.. }\end{array}$ \\
\hline ZSA (salps) & $\begin{array}{l}\text { A nominal value that reflects } \\
\text { the low abundance of this } \\
\text { taxon in the SG area (Ward } \\
\text { et al. 1995, Atkinson et al. } \\
\text { 1996, Pakhomov et al. } \\
\text { 1997b) particularly over its } \\
\text { shelf }\end{array}$ & $\begin{array}{l}7.6 \\
\text { In the absence of direct data from } \\
\text { South Georgia we used the Q/B value } \\
\text { multiplied by a GGE of } 25 \% \text { (Straile } \\
\text { 1997) }\end{array}$ & $\begin{array}{l}30.4 \\
\text { Based on a daily C ration of 25\% } \\
\text { (Pakhomov et al. 2006) and a } 4 \\
\text { month feeding season (von } \\
\text { Harbou et al. in press) }\end{array}$ & $\begin{array}{l}\text { PHY 45, ZHT45, BAC 6, ZHE 1, ZCO } 2 \\
\text { Based on a roughly 50:50 ratio of } \\
\text { diatoms versus protozoans plus } \\
\text { small metazoans (Hopkins and } \\
\text { Torres 1988). A nominal remaining } \\
10 \% \text { is divided into bacteria } \\
\text { (associated with detrital aggregates } \\
\text { and incidental capture of larger } \\
\text { metazoans }\end{array}$ \\
\hline $\begin{array}{l}\text { ZHT (Heterotrophic } \\
\text { microplankton < } \\
200 \text { microns: } \\
\text { crustacean larvae, } \\
\text { ciliates, } \\
\text { dinoflagellates, } \\
\text { microflagellates) }\end{array}$ & $\begin{array}{l}20.3 \\
\text { Biomass of protists is } 1.138 \\
\mathrm{gC} \mathrm{m}^{-2} \text { based on integrated } \\
\text { water column value from } 2 \\
\text { stations at NW shelf and } \\
\text { shelfbreak at SG (Priddle et } \\
\text { al. 1995). } \\
\text { The assumed C to WM } \\
\text { conversion factor was } 10 . \\
\text { The above value for protists } \\
\text { is added to a micrometazoan } \\
\text { value of } 2.23 g D M m^{-2} \text { based } \\
\text { on the difference between } \\
53 \mu \mathrm{m} \text { and } 200 \mu \mathrm{m} \text { catches } \\
\text { in northern Scotia Sea (Ward } \\
\text { et al. in review this volume). }\end{array}$ & $\begin{array}{l}\mathbf{4 7 . 2} \\
\text { This is derived from a daily P/B ratio } \\
\text { for SG system from Spring, summer } \\
\text { and autumn cruises (Korb et al. this } \\
\text { volume). Chl a was thus converted to } \\
\text { carbon using SG-derived C:chl ratio of } \\
75 \text { (Priddle et al. 1995). This mean } \\
\text { daily P/B ratio for autotrophs of } 0.194 \\
\text { was assumed as similar to that of } \\
\text { autotrophs which are of similar size in } \\
\text { SG system and unlike atotrophs can } \\
\text { grow round the clock. Production is } \\
\text { based on } 8 \text { months of year where chl } \\
\text { levels are elevated (Whitehouse et al. } \\
\text { in review, this volume) }\end{array}$ & $\begin{array}{l}163 \\
\text { Based on the P/B ratio divided by } \\
\text { a GGE of } 0.29 \text {, a value } \\
\text { representative of protozoans } \\
\text { (Straile 1997). This equates to a } \\
\text { daily C ration of } 67 \% \text { per day, } \\
\text { sustained over a } 8 \text { month season } \\
\text { of elevated chl } a \text { (see P/B column) }\end{array}$ & $\begin{array}{l}\text { PHY 60, PBA } 40 \\
\text { This is simply a nominal value. Like } \\
\text { the other values for heterotrophic } \\
\text { microplankton it is very poorly } \\
\text { constrained). These values are } \\
\text { poorly constrained because this ZHT } \\
\text { box contains up to } 3 \text { trophic levels } \\
\text { (including, heterotrophic } \\
\text { nanoflagellates, large dinoflagellates, } \\
\text { small crustaceans) }\end{array}$ \\
\hline
\end{tabular}


TABLE 2 Summary of the scenarios explored.

\begin{tabular}{|c|c|c|}
\hline Scenario & Mid-trophic levels & Predator response \\
\hline S1 & $\begin{array}{l}\text { On-shelf } \text { krill biomass reduced by } 80 \% \text { ( } 26 \\
\text { t.km }{ }^{-2} \text { ). Availability of off-shelf krill also } \\
\text { reduced by } 80 \% \text {. }\end{array}$ & Diets unchanged. \\
\hline S2 & $\begin{array}{l}\text { On-shelf } \text { krill biomass reduced by } 80 \% \text { ( } 26 \\
\text { t.km }{ }^{-2} \text { ). Availability of off-shelf krill also } \\
\text { reduced by } 80 \% \text {. }\end{array}$ & $\begin{array}{l}\text { Diet switching from krill and off-shelf krill } \\
\text { to on-shelf carnivorous macroplankton } \\
\text { and copepods. }\end{array}$ \\
\hline S3 & $\begin{array}{l}\text { On-shelf } \text { krill biomass reduced by } 80 \% \text { ( } 26 \\
\text { t.km }{ }^{-2} \text { ). Availability of off-shelf krill also } \\
\text { reduced by } 80 \% \text {. Copepod biomass } \\
\text { increased by } 26.17 \mathrm{t} \mathrm{km}^{-2}\end{array}$ & Diets unchanged. \\
\hline S4 & $\begin{array}{l}\text { On-shelf krill biomass reduced by } 80 \% \text { ( } 26 \\
\text { t.km }{ }^{-2} \text { ). Availability of off-shelf krill also } \\
\text { reduced by } 80 \% \text {. Copepod biomass } \\
\text { increased by } 26.17 \mathrm{t} \mathrm{km}^{-2}\end{array}$ & $\begin{array}{l}\text { Diet switching from krill and off-shelf krill } \\
\text { to on-shelf carnivorous macroplankton } \\
\text { and copepods. }\end{array}$ \\
\hline
\end{tabular}


TABLE 3: Input (base data) and balanced (model) values of non-diet input variables for all functional groups represented in the models.

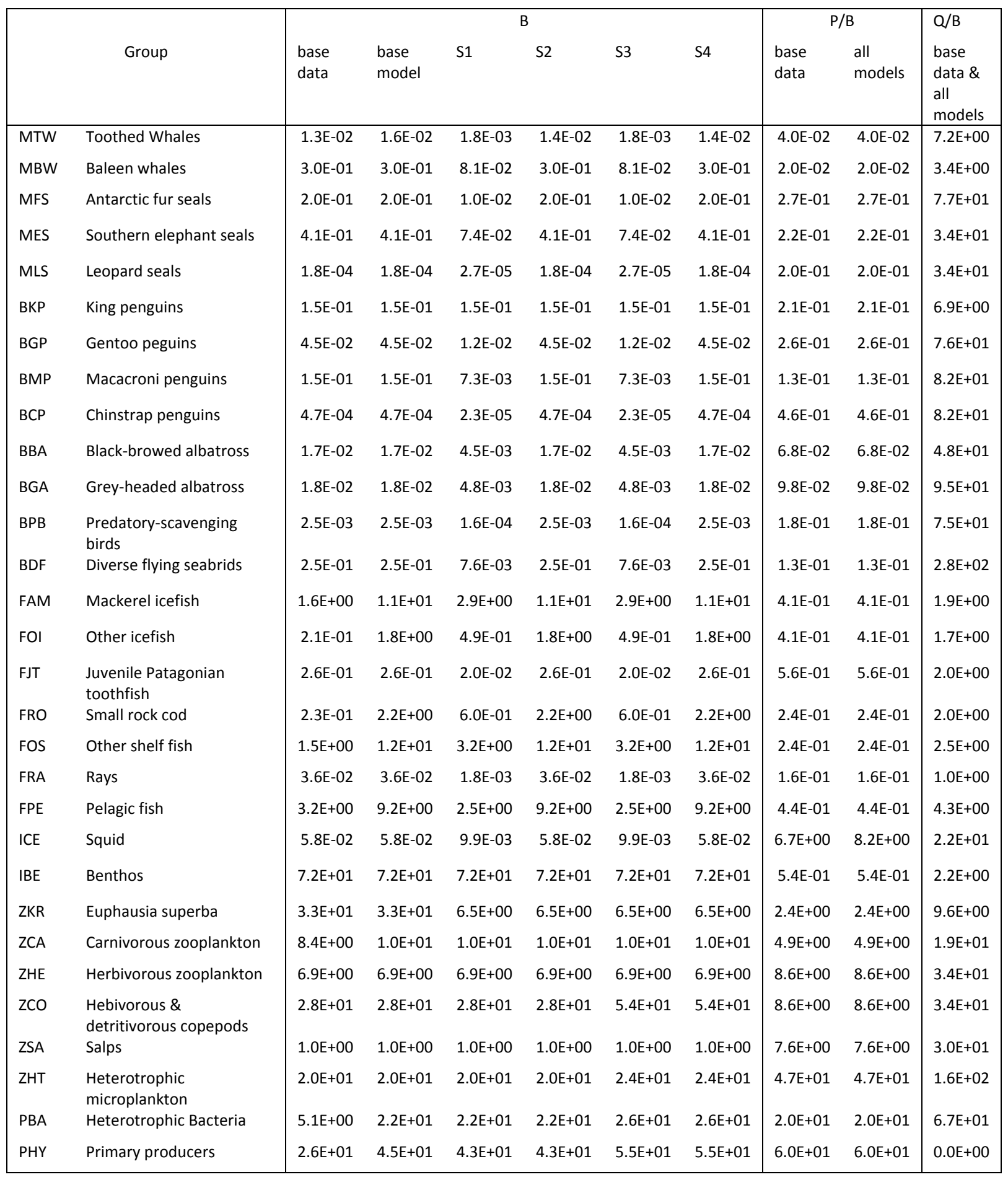


TABLE 4a: Diet matrix for the base model (vertebrate predators). The table demonstrates the method used to distinguish off-shelf feeding on krill (EIM1) from off-shelf feeding on other prey (EIM2): The off-shelf prey were modelled as discrete functional groups, each feeding each feeding entirely on "Import".

\begin{tabular}{|c|c|c|c|c|c|c|c|c|c|c|c|c|c|c|c|c|c|c|c|c|}
\hline $\begin{array}{l}\text { Prey } \backslash \\
\text { predator }\end{array}$ & MTW & MBW & MFS & MES & MLS & BKP & BGP & BMP & BCP & BBA & BGA & BPB & BDF & FAM & FOI & FJT & FRO & FOS & FRA & FPE \\
\hline MBW & & & & & & & & & & & & & & & & & & & & \\
\hline MFS & $5.9 \mathrm{E}-03$ & & & & 3.3E-01 & & & & & & & $3.9 \mathrm{E}-03$ & & & & & & & & \\
\hline MES & & & & & $3.0 \mathrm{E}-03$ & & & & & & & $1.3 \mathrm{E}-03$ & & & & & & & & \\
\hline MLS & $2.0 \mathrm{E}-05$ & & & & & & & & & & & & & & & & & & & \\
\hline BKP & $2.0 \mathrm{E}-03$ & & & & & & & & & & & $5.4 \mathrm{E}-02$ & & & & & & & & \\
\hline BGP & & & & & $2.1 \mathrm{E}-01$ & & & & & & & $2.6 \mathrm{E}-02$ & & & & & & & & \\
\hline BMP & & & & & $7.0 \mathrm{E}-03$ & & & & & & & $5.1 \mathrm{E}-02$ & & & & & & & & \\
\hline BCP & & & & & & & & & & & & & & & & & & & & \\
\hline BBA & & & & & & & & & & & & $2.6 \mathrm{E}-03$ & & & & & & & & \\
\hline BGA & & & & & & & & & & & & $1.3 \mathrm{E}-03$ & & & & & & & & \\
\hline BPB & & & & & & & & & & & & $1.0 \mathrm{E}-03$ & & & & & & & & \\
\hline BDF & & & & & & & & & & & & $8.4 \mathrm{E}-02$ & & & & & & & & \\
\hline FAM & $4.1 \mathrm{E}-02$ & & $1.3 \mathrm{E}-02$ & $5.0 \mathrm{E}-03$ & & $1.0 \mathrm{E}-02$ & $2.0 \mathrm{E}-01$ & $1.2 \mathrm{E}-01$ & $1.1 \mathrm{E}-02$ & $2.7 \mathrm{E}-02$ & $8.0 \mathrm{E}-03$ & & $1.3 \mathrm{E}-04$ & & $1.1 \mathrm{E}-01$ & $3.8 \mathrm{E}-02$ & & $5.2 \mathrm{E}-02$ & & \\
\hline FOI & $5.5 \mathrm{E}-03$ & & $2.7 \mathrm{E}-03$ & $3.5 \mathrm{E}-03$ & & & & & & & & & $2.4 \mathrm{E}-05$ & $2.0 \mathrm{E}-02$ & $5.0 \mathrm{E}-03$ & $2.9 \mathrm{E}-02$ & & $7.5 \mathrm{E}-03$ & $3.9 \mathrm{E}-02$ & \\
\hline FJT & $6.6 \mathrm{E}-03$ & & & & & & & & & & & $6.6 \mathrm{E}-03$ & $4.8 \mathrm{E}-05$ & & & & & & & \\
\hline FRO & $5.9 \mathrm{E}-03$ & & $1.4 \mathrm{E}-03$ & & & $1.0 \mathrm{E}-02$ & $4.5 \mathrm{E}-03$ & & $1.1 \mathrm{E}-02$ & & & & $1.1 \mathrm{E}-04$ & & $3.9 \mathrm{E}-02$ & $3.1 \mathrm{E}-01$ & $2.7 \mathrm{E}-02$ & & $1.4 \mathrm{E}-01$ & \\
\hline FOS & $4.0 \mathrm{E}-02$ & & $1.3 \mathrm{E}-02$ & $2.0 \mathrm{E}-02$ & & $5.0 \mathrm{E}-03$ & $1.6 \mathrm{E}-03$ & $9.0 \mathrm{E}-02$ & $1.7 \mathrm{E}-02$ & $2.1 \mathrm{E}-02$ & $6.1 \mathrm{E}-03$ & & $1.8 \mathrm{E}-04$ & $3.0 \mathrm{E}-02$ & $1.5 \mathrm{E}-01$ & $1.3 \mathrm{E}-01$ & & & $2.2 \mathrm{E}-01$ & \\
\hline FRA & $9.4 \mathrm{E}-04$ & & & & & & & & & & & & & & & & & & $3.7 \mathrm{E}-05$ & \\
\hline FPE & $7.3 \mathrm{E}-02$ & & $3.7 \mathrm{E}-02$ & $3.0 \mathrm{E}-02$ & & $7.5 \mathrm{E}-02$ & $5.0 \mathrm{E}-04$ & $6.1 \mathrm{E}-02$ & $3.9 \mathrm{E}-02$ & & & & $6.2 \mathrm{E}-03$ & & $1.0 \mathrm{E}-02$ & $6.8 \mathrm{E}-02$ & & $5.6 \mathrm{E}-02$ & & \\
\hline ICE & $2.0 \mathrm{E}-02$ & & 7.7E-04 & $3.2 \mathrm{E}-02$ & & & & $1.3 \mathrm{E}-03$ & 8.1E-04 & & & & $1.3 \mathrm{E}-04$ & & & $1.5 \mathrm{E}-02$ & & & $8.3 \mathrm{E}-02$ & \\
\hline IBE & & & & & & & & & & & & & & & $2.4 \mathrm{E}-01$ & $7.6 \mathrm{E}-02$ & $4.5 \mathrm{E}-02$ & $2.0 \mathrm{E}-02$ & $4.1 \mathrm{E}-01$ & \\
\hline
\end{tabular}




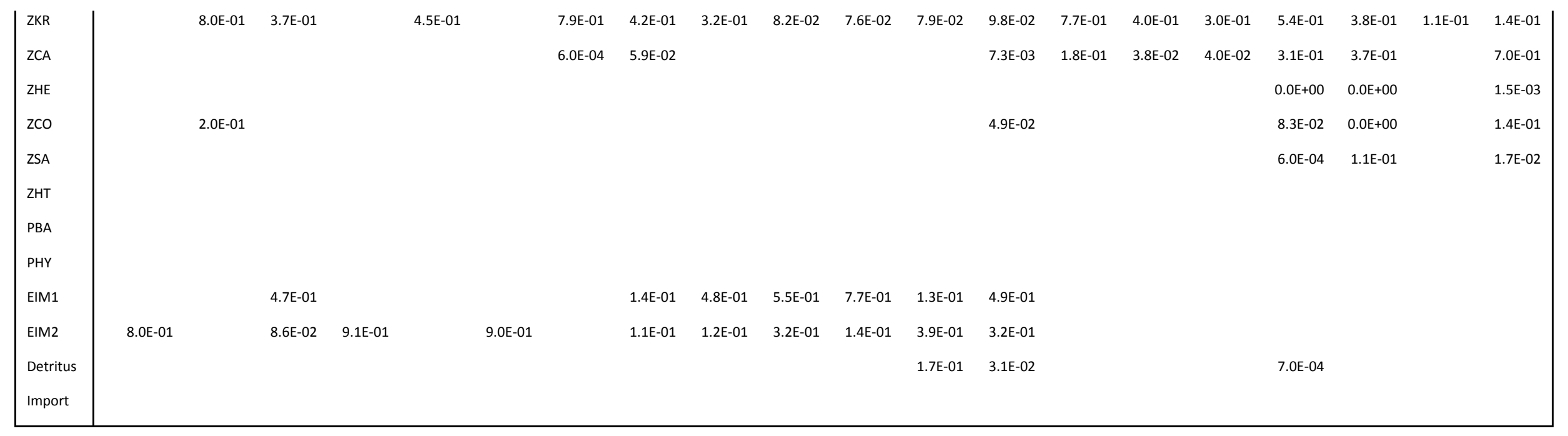


TABLE 4b: Diet matrix for the base model (invertebrate predators and off-shelf goups).

\begin{tabular}{|c|c|c|c|c|c|c|c|c|c|c|c|}
\hline $\begin{array}{l}\text { Prey } \backslash \\
\text { predator }\end{array}$ & ICE & IBE & ZKR & ZCA & $\mathrm{ZHE}$ & $\mathrm{ZCO}$ & ZSA & $\mathrm{ZHT}$ & PBA & EIM1 & EIM2 \\
\hline FJT & $5.0 \mathrm{E}-02$ & & & & & & & & & & \\
\hline FRO & 5.0E-02 & & & & & & & & & & \\
\hline FOS & 5.0E-02 & & & & & & & & & & \\
\hline FRA & & & & & & & & & & & \\
\hline FPE & 5.0E-02 & & & & & & & & & & \\
\hline ICE & & & & & & & & & & & \\
\hline IBE & 1.5E-01 & 8.9E-02 & & & & & & & & & \\
\hline ZKR & 2.5E-01 & & & & & & & & & & \\
\hline ZCA & 1.0E-01 & 4.7E-04 & $1.0 \mathrm{E}-02$ & & & & & & & & \\
\hline ZHE & & 4.7E-04 & 5.0E-03 & $1.5 \mathrm{E}-01$ & & & $2.0 \mathrm{E}-02$ & & & & \\
\hline $\mathrm{ZCO}$ & 3.0E-01 & $2.4 \mathrm{E}-04$ & $1.5 \mathrm{E}-02$ & $5.4 \mathrm{E}-01$ & & & $2.0 \mathrm{E}-02$ & & & & \\
\hline ZSA & & & & 1.0E-02 & & & & & & & \\
\hline ZHT & & $1.9 \mathrm{E}-01$ & 4.5E-01 & 1.0E-01 & 5.0E-01 & 5.0E-01 & $4.5 \mathrm{E}-01$ & & & & \\
\hline PBA & & 2.0E-01 & & & 8.0E-02 & 8.0E-02 & $6.0 \mathrm{E}-02$ & 4.0E-01 & & & \\
\hline PHY & & 5.1E-01 & $4.2 \mathrm{E}-01$ & 1.0E-01 & 4.0E-01 & 4.0E-01 & 4.5E-01 & 6.0E-01 & & & \\
\hline EIM1 & & & & & & & & & & & \\
\hline EIM2 & & & & & & & & & & & \\
\hline Detritus & & $1.5 \mathrm{E}-02$ & 1.0E-01 & 1.0E-01 & 2.0E-02 & 2.0E-02 & & & $1.0 \mathrm{E}+00$ & & \\
\hline Import & & & & & & & & & & $1.0 \mathrm{E}+00$ & $1.0 \mathrm{E}+00$ \\
\hline
\end{tabular}


TABLE 5: Summary statistics for the base dataset and balanced models. All estimates exclude detritus unless otherwise indicated. EE (overall) and mean trophic level are biomass weighted averages.

\begin{tabular}{|c|c|c|c|c|c|c|c|}
\hline Statistic & base data & base model & S1 & $\mathrm{S} 2$ & S3 & S4 & units \\
\hline B (total) & 208 & 274 & 219 & 246 & 266 & 293 & t. $\mathrm{km}^{-2}$ \\
\hline B (UTL) & 9 & 38 & 10 & 38 & 10 & 38 & t. $\mathrm{km}^{-2}$ \\
\hline B (ZOO) & 77 & 78 & 52 & 52 & 78 & 78 & t. $\mathrm{km}^{-2}$ \\
\hline P (total) & 3,058 & 4,578 & 4,400 & 4,409 & 5,624 & 5,635 & $\mathrm{t} \cdot \mathrm{km}^{-2} \cdot \mathrm{yr}^{-1}$ \\
\hline P (UTL) & 3 & 13 & 4 & 13 & 4 & 13 & t. $\mathrm{km}^{-2} \cdot \mathrm{yr}^{-1}$ \\
\hline P (ZOO) & 424 & 432 & 369 & 369 & 594 & 594 & t. $\mathrm{km}^{-2} \cdot \mathrm{yr}^{-1}$ \\
\hline PP & 1,534 & 2,702 & 2,597 & 2,597 & 3,324 & 3,324 & $\mathrm{t} \cdot \mathrm{km}^{-2} \cdot \mathrm{yr}^{-1}$ \\
\hline $\mathrm{Q}$ (total) & 5,634 & 6,851 & 6,419 & 6,600 & 8,248 & 8,429 & t. $\mathrm{km}^{-2} \cdot \mathrm{yr}^{-1}$ \\
\hline $\mathrm{Q}$ (of detritus) & 414 & 1528 & 1501 & 1503 & 1835 & 1838 & t. $\mathrm{km}^{-2} \cdot \mathrm{yr}^{-1}$ \\
\hline $\mathrm{Q}$ (of imports) & 83 & 83 & 6 & 55 & 6 & 55 & t. $\mathrm{km}^{-2} \cdot \mathrm{yr}^{-1}$ \\
\hline $\mathrm{Q}$ (of ZKR) & 27 & 58 & 12 & 16 & 12 & 16 & \\
\hline$Q($ of ZCA) & 16 & 49 & 13 & 49 & 13 & 49 & t. $\mathrm{km}^{-2} \cdot \mathrm{yr}^{-1}$ \\
\hline$Q$ (of ZCO) & 100 & 120 & 108 & 184 & 108 & 184 & t. $\mathrm{km}^{-2} \cdot \mathrm{yr}^{-1}$ \\
\hline EE (overall) & 1.68 & 0.92 & 0.89 & 0.91 & 0.92 & 0.94 & \\
\hline $\begin{array}{l}\text { Mean trophic } \\
\text { level }\end{array}$ & 2.51 & 2.54 & 2.34 & 2.55 & 2.32 & 2.50 & \\
\hline
\end{tabular}

$\mathrm{UTL}=$ upper trophic levels (mammals, birds, fish and cephalopods); ZOO=zooplankton (excluding ZHT); B=biomass; $\mathrm{P}=$ production; $\mathrm{PP}=$ primary production; $\mathrm{Q}=$ consumption. 
TABLE 6: Trophic level and Ecotrophic efficiency (EE) for all trophic groups in the models. Trophic level is calculated as $1+$ the mean trohic level of a predator's prey groups, weighted by their contribution to the predator's diet, where detritus and primary producers have a trophic level of 1 . Bold values indicate "unbalanced" ecotrophic efficiencies (>1) in the base dataset.

\begin{tabular}{|c|c|c|c|c|c|c|c|c|c|c|c|c|}
\hline \multirow[b]{2}{*}{ Group } & \multicolumn{6}{|c|}{ Trophic level } & \multicolumn{6}{|c|}{$\mathrm{EE}$} \\
\hline & base data & base model & S1 & S2 & S3 & S4 & base data & base model & S1 & S2 & S3 & S4 \\
\hline MTW & 5.20 & 5.10 & 5.10 & 5.10 & 5.10 & 5.10 & 0.00 & 0.00 & 0.00 & 0.00 & 0.00 & 0.00 \\
\hline MBW & 3.71 & 3.71 & 3.71 & 3.77 & 3.71 & 3.77 & 0.00 & 0.00 & 0.00 & 0.00 & 0.00 & 0.00 \\
\hline MFS & 3.92 & 3.91 & 3.91 & 3.89 & 3.91 & 3.89 & 0.06 & 0.06 & 0.16 & 0.06 & 0.16 & 0.06 \\
\hline MES & 5.18 & 5.11 & 5.11 & 5.06 & 5.11 & 5.06 & 0.00 & 0.00 & 0.00 & 0.00 & 0.00 & 0.00 \\
\hline MLS & 4.43 & 4.37 & 4.37 & 4.48 & 4.37 & 4.48 & 5.53 & 0.06 & 0.05 & 0.06 & 0.05 & 0.06 \\
\hline BKP & 5.16 & 5.13 & 5.13 & 4.89 & 5.13 & 4.89 & 0.32 & 0.32 & 0.02 & 0.32 & 0.02 & 0.32 \\
\hline BGP & 4.19 & 3.94 & 3.93 & 4.47 & 3.94 & 4.47 & 0.54 & 0.54 & 0.16 & 0.54 & 0.16 & 0.54 \\
\hline BMP & 4.26 & 4.23 & 4.22 & 4.58 & 4.23 & 4.58 & 0.51 & 0.51 & 0.65 & 0.51 & 0.66 & 0.51 \\
\hline $\mathrm{BCP}$ & 3.98 & 3.97 & 3.97 & 3.95 & 3.97 & 3.95 & 0.00 & 0.00 & 0.00 & 0.00 & 0.00 & 0.00 \\
\hline BBA & 4.21 & 4.17 & 4.17 & 4.29 & 4.17 & 4.29 & 0.45 & 0.45 & 0.10 & 0.45 & 0.10 & 0.45 \\
\hline BGA & 3.91 & 3.89 & 3.89 & 3.94 & 3.89 & 3.94 & 0.15 & 0.15 & 0.03 & 0.15 & 0.03 & 0.15 \\
\hline BPB & 3.84 & 3.80 & 3.80 & 3.87 & 3.80 & 3.87 & 3.85 & 0.42 & 0.42 & 0.42 & 0.42 & 0.42 \\
\hline BDF & 3.52 & 3.52 & 3.52 & 3.70 & 3.52 & 3.70 & 0.49 & 0.49 & 0.99 & 0.49 & 1.00 & 0.49 \\
\hline FAM & 4.03 & 3.88 & 3.88 & 4.33 & 3.88 & 4.33 & 4.45 & 1.00 & 0.69 & 1.00 & 0.69 & 1.00 \\
\hline FOI & 4.98 & 4.11 & 4.11 & 4.42 & 4.11 & 4.42 & 2.48 & 1.00 & 0.91 & 1.00 & 0.91 & 1.00 \\
\hline FJT & 5.03 & 4.49 & 4.49 & 4.64 & 4.49 & 4.64 & 0.49 & 0.49 & 0.99 & 0.49 & 0.99 & 0.49 \\
\hline FRO & 4.03 & 3.94 & 3.94 & 3.80 & 3.94 & 3.80 & 10.10 & 1.00 & 0.74 & 1.00 & 0.74 & 1.00 \\
\hline FOS & 4.18 & 4.11 & 4.11 & 4.33 & 4.11 & 4.33 & 7.92 & 1.00 & 0.57 & 1.00 & 0.57 & 1.00 \\
\hline FRA & 4.38 & 4.31 & 4.31 & 4.35 & 4.31 & 4.35 & 0.02 & 0.02 & 0.04 & 0.02 & 0.04 & 0.02 \\
\hline FPE & 4.19 & 4.19 & 4.19 & 3.81 & 4.19 & 3.81 & 1.82 & 1.00 & 0.65 & 1.00 & 0.65 & 1.00 \\
\hline ICE & 4.11 & 4.07 & 4.07 & 4.03 & 4.07 & 4.03 & 1.21 & 1.00 & 1.00 & 1.00 & 1.00 & 1.00 \\
\hline IBE & 2.60 & 2.60 & 2.60 & 2.60 & 2.60 & 2.60 & 0.36 & 0.40 & 0.37 & 0.40 & 0.37 & 0.40 \\
\hline ZKR & 2.69 & 2.69 & 2.69 & 2.68 & 2.69 & 2.68 & 0.34 & 0.74 & 0.74 & 1.00 & 0.74 & 1.00 \\
\hline ZCA & 3.39 & 3.39 & 3.39 & 3.39 & 3.39 & 3.39 & 0.40 & 1.00 & 0.26 & 1.00 & 0.26 & 1.00 \\
\hline ZHE & 2.78 & 2.78 & 2.78 & 2.78 & 2.78 & 2.78 & 0.45 & 0.53 & 0.51 & 0.51 & 0.51 & 0.51 \\
\hline
\end{tabular}




\begin{tabular}{|l|rrrrrr|rrrrrr|}
\hline ZCO & 2.78 & 2.78 & 2.78 & 2.78 & 2.78 & 2.78 & 0.42 & 0.50 & 0.46 & 0.77 & 0.23 & 0.40 \\
ZSA & 2.76 & 2.76 & 2.76 & 2.76 & 2.76 & 2.76 & 0.30 & 0.78 & 0.40 & 0.78 & 0.40 & 0.78 \\
ZHT & 2.40 & 2.40 & 2.40 & 2.40 & 2.40 & 2.40 & 0.83 & 0.83 & 0.71 & 0.71 & 1.00 & 1.00 \\
PBA & 2.00 & 2.00 & 2.00 & 2.00 & 2.00 & 2.00 & 14.28 & 1.00 & 1.00 & 1.00 & 1.00 & 1.00 \\
PHY & 1.00 & 1.00 & 1.00 & 1.00 & 1.00 & 1.00 & 1.76 & 1.00 & 1.00 & 1.00 & 1.00 & 1.00 \\
DET & 1.00 & 1.00 & 1.00 & 1.00 & 1.00 & 1.00 & 0.00 & 0.80 & 0.78 & 0.84 & 0.82 & 0.87 \\
\hline
\end{tabular}


Fig 1: The modelled area (South Georgia shelf to the $1000 \mathrm{~m}$ isobath) in the regional (A) and (B) local context.
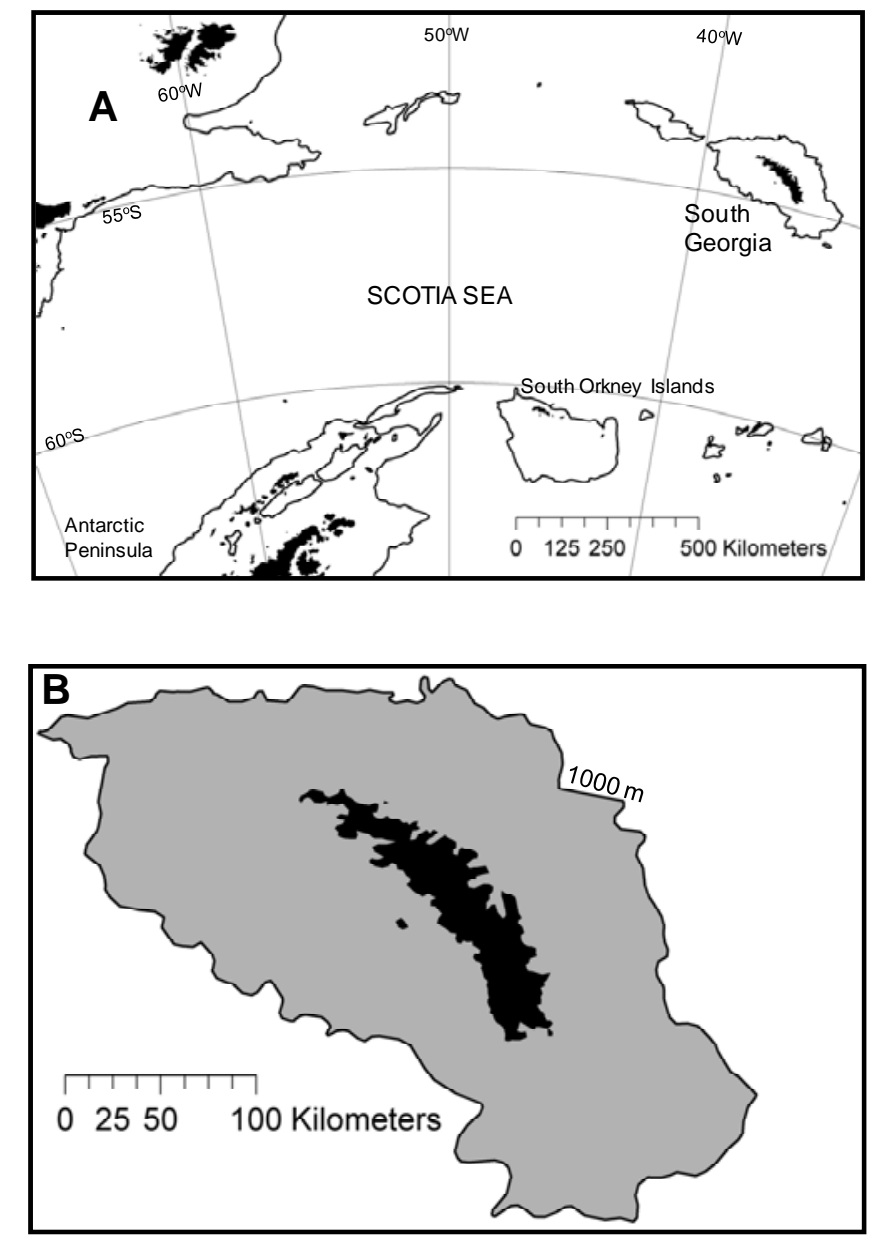
Fig 2: The trophic role of Antarctic krill showing flow rates from its prey and to its main predators (in the base dataset and, in parentheses, the base model).

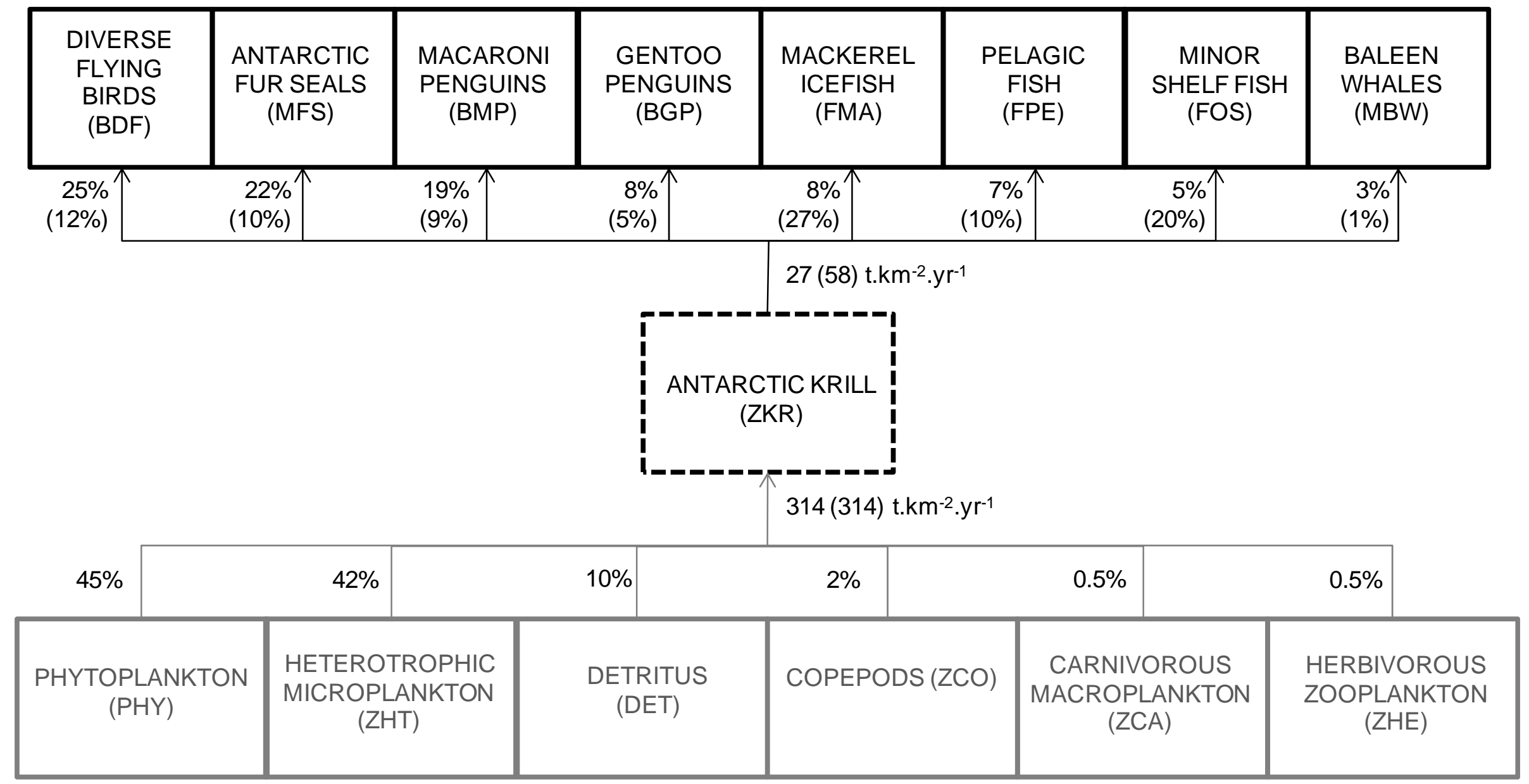


Fig 3: The trophic role of herbivorous and detritivorous copepods showing flow rates from their prey (in the base dataset) and to their main predators (in the base dataset and, in parentheses, the base model).

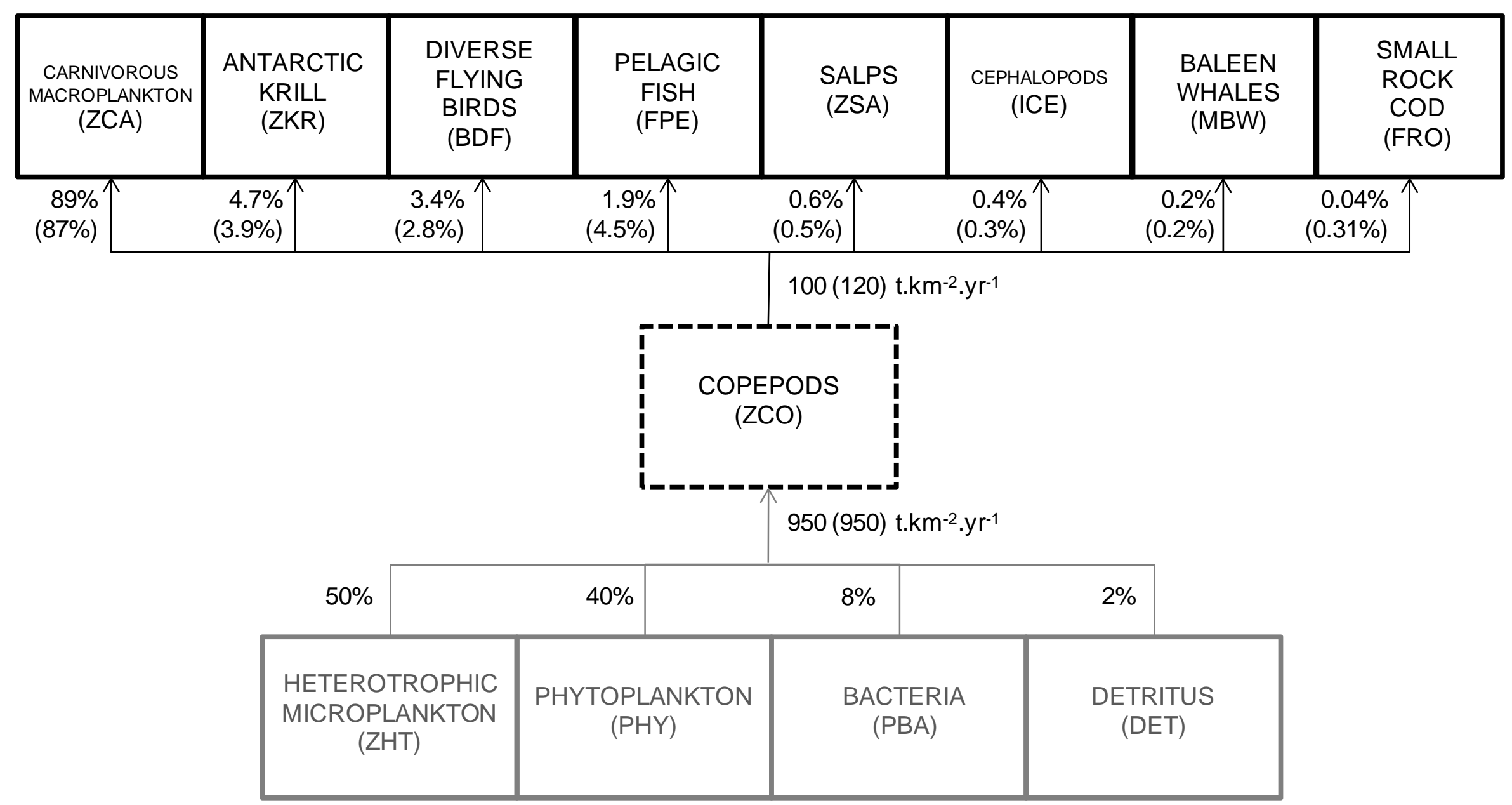


Figure 4: Production by higher trophic level taxa $(M=$ mammals, $A(P)=$ penguins, $A(F)=f l y i n g$ seabirds,

$F(D)=$ demersal fish, $F(P)=$ pelagic fish, $C=$ cephalopods) in the base dataset, the base model, and switching (S2 \& S4) and non switching (S1 \& S3) scenario models.
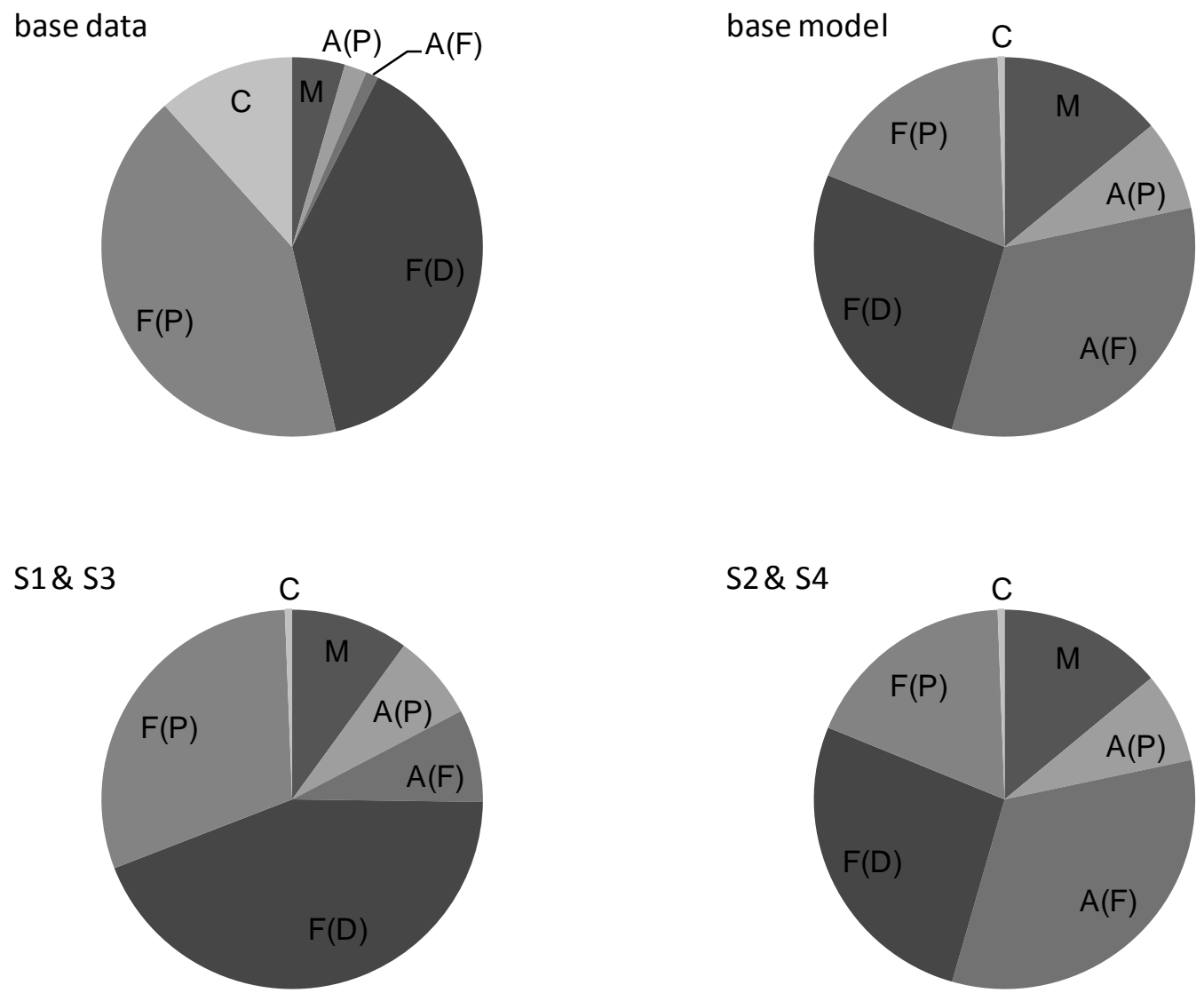